\title{
Long-Term Effects of Leaving Military Service in a Weak Economy
}

\author{
Italo A. Gutierrez and Jennie W. Wenger
}




\title{
Long-Term Effects of Leaving Military Service in a Weak Economy
}

\author{
Italo A. Gutierrez \\ RAND Corporation \\ Jennie W. Wenger \\ RAND Corporation
}

September 2017

\author{
Michigan Retirement Research Center \\ University of Michigan \\ P.O. Box 1248 \\ Ann Arbor, MI 48104 \\ www.mrrc.isr.umich.edu \\ (734) 615-0422
}

\section{Acknowledgements}

The research reported herein was performed pursuant to a grant from the U.S. Social Security Administration (SSA) funded as part of the Retirement Research Consortium through the University of Michigan Retirement Research Center Award RRC08098401-09. The opinions and conclusions expressed are solely those of the author(s) and do not represent the opinions or policy of SSA or any agency of the federal government. Neither the United States government nor any agency thereof, nor any of their employees, makes any warranty, express or implied, or assumes any legal liability or responsibility for the accuracy, completeness, or usefulness of the contents of this report. Reference herein to any specific commercial product, process or service by trade name, trademark, manufacturer, or otherwise does not necessarily constitute or imply endorsement, recommendation or favoring by the United States government or any agency thereof.

\section{Regents of the University of Michigan}

Michael J. Behm, Grand Blanc; Mark J. Bernstein, Ann Arbor; Shauna Ryder Diggs, Grosse Pointe; Denise Ilitch, Bingham Farms; Andrea Fischer Newman, Ann Arbor; Andrew C. Richner, Grosse Pointe Park; Ron Weiser, Ann Arbor; Katherine E. White, Ann Arbor; Mark S. Schlissel, ex officio 


\title{
Long-Term Effects of Leaving Military Service in a Weak Economy
}

\begin{abstract}
Previous research finds negative effects in the short and medium term for those who initially entered the labor force during weak labor markets. Discerning the effects of initial market conditions is difficult as young workers may attempt to time their entry by, for example, spending additional time in school during weak markets. In this paper, we take advantage of a novel form of exogenous variation that affected a large group of older workers to study longerterm effects of entering labor markets during bad economic times. Using the Health and Retirement Study, we focus on veterans from the draft era and examine the effects of leaving military service during periods of high unemployment on earnings, wealth, and retirement. These men had little choice about the timing of entry into the labor force; they generally were drafted or volunteered based on world events, and they left the military at the end of fixed contracts after short terms of service. Our results indicate that draft-era veterans who entered the labor force during a weaker economy had lower levels of earnings, and the effects lasted for more than a decade. We also find that while veterans who enter weak labor markets eventually catch up with other veterans in terms of earnings, the accumulated negative effects on wealth and financial preparedness for retirement are large; we find some evidence that veterans compensate by extending their working lives.
\end{abstract}

\section{Citation}

Gutierrez, Italo A., and Jennie W. Wenger. 2017. “Long-Term Effects of Leaving Military Service in a Weak Economy.” Ann Arbor MI: University of Michigan Retirement Research Center (MRRC) Working Paper, WP 2017-369. http://mrrc.isr.umich.edu/wp369/

\section{Authors' acknowledgements}

We gratefully acknowledge the assistance of Anita Szafran and Sujeong Park at RAND. Finally, we are grateful to participants at the Michigan Retirement Research Center Researcher Workshop in Ann Arbor, MI (March-April 2017) and to participants at the Western Economic Association Annual Conference in San Diego, CA (June 2017) for their comments and suggestions. 


\section{Introduction and Background}

To some extent, when each person enters the job market is determined by luck: timing of their birth, schooling, and training. Some people search for a first job during a strong labor market with plentiful jobs and substantial wage growth; others face very different circumstances, perhaps entering during a downturn or a recession in which jobs are scarcer and wages are lower. More than three million job-seekers enter the labor force each year; thus, millions of young adults entered the labor force during the most recent downturn (the Great Recession). ${ }^{1}$

Previous literature has studied the negative effects of entering the labor market in a recession on earnings and income for several groups: high school graduates (Hershbein, 2012); college graduates (Kahn, 2010; Oreopoulos, von Wachter, and Heisz, 2012); Ph.D. and MBA graduates (Oyer, 2006, 2008); and prime-age male workers (Beaudry and DiNardo, 1991; Brunner and Kuhn, 2009; Genda, Kondo, and Ohta, 2010). Across these groups, research consistently shows that the negative effects of entering the labor market during a recession are sizeable and last for a number of years, at least through the first one to two decades of the workers’ careers. Existing results imply large and substantial accumulated effects. Moreover, these effects can be found in measures other than wages. Entering a weak labor market influences eventual post-secondary educational attainment and also appears to result in somewhat lower occupational status (Kahn, 2010). However, despite the extensive research on this subject, very little is known about the longer-term effects of entering the labor market during a recession and the extent to which this timing influences wealth, savings, or retirement. Given the sequential nature of wages, such early differences could be reflected throughout the entire course of a worker's career and could even influence saving for and timing of retirement

\footnotetext{
1 See https://www.bls.gov/emp/ep_table_305.htm
} 
although the likely direction of the effects is not clear. For example, those who enter the labor market during a recessionary period could work longer, or could retire earlier as the opportunity cost of doing so might be lower.

Obtaining a better understanding of the longer-term effects of recessions on workers’ careers would be especially valuable in the current environment, in which many young workers entered the labor force during the recent, severe recession. In other words, understanding the longer-term impacts of initial conditions on workers and their retirement decisions would provide information that could be very useful in predicting the retirement behavior and financial preparedness of tomorrow's retirees.

One potential criticism of existing work is that entry into the labor force can, in some cases, be timed based on economic conditions. For example, Kahn (2010) finds that those who completed college during weaker labor markets had higher levels of educational attainment (but lower earnings): This suggests that workers may pursue additional education during weak economies. To help circumvent this issue, we take advantage of a novel form of exogenous variation; we examine the long-term earnings of older veterans from the draft era. These men had little choice about the timing of entry into the labor force; they generally were drafted or volunteered based on world events, and they left the military at the end of fixed contracts after short terms of service.

To focus on young workers who enter the labor force after a short time in the military, we include only veterans who served no more than five years. ${ }^{2}$ These veterans emerge from the military in a situation that is somewhat similar to college graduates — with recently acquired

\footnotetext{
2 Most veterans, in the past and today, serve less than five years. Veterans who serve at least 20 years are eligible for military retirement; this benefit, which begins immediately upon exiting the military, is likely to impact a variety of labor market choices. To avoid the influence of retirement and to capture those least likely to time their exit from the military (by, for example, serving additional terms), we focus on veterans with short periods of service.
} 
human capital but with limited (civilian) labor market experience. Their timing of entry into the civilian labor force was determined primarily by the end of their contracts, providing a source of arguably exogenous variation.

We also note that there is a well-developed literature examining the question of how military service influences educational attainment and eventual civilian earnings (see for example, Angrist, 1990; Angrist and Chen, 2011; Angrist and Krueger, 1994; Bound and Turner, 2002; Loughran et al., 2011). While the literature comparing veterans and non-veterans has important policy implications, it focuses on a different question than the one we examine here. Our focus is on the long-term impact of labor market conditions at re-entry into the civilian labor force. Therefore, rather than comparing veterans to nonveterans, we compare veterans who entered strong civilian labor markets with similar veterans who entered weaker civilian markets. Therefore, this research is in the spirit of Kahn (2010) and similar papers.

We use the Health and Retirement Study (HRS) in our study. ${ }^{3}$ This dataset provides the opportunity to examine the effects of entering the civilian labor market during a recession on veterans' earnings through their entire careers, on their retirement decisions, and on their financial preparedness for retirement (measured by wealth, including Social Security and pension wealth). Our findings provide relevant information on how current economic conditions may affect today's young workers' eventual preparation for and timing of retirement, and thus should be of interest to policymakers at the SSA. Our findings should also be of interest to policymakers working to smooth current veterans’ transitions into the civilian labor force.

Our paper is structured as follows: In Section 2, we describe the draft era in America, including the number of veterans that served in each era and common periods of service; in

\footnotetext{
3 The HRS (Health and Retirement Study) is sponsored by the National Institute on Aging (grant number NIA U01AG009740) and is conducted by the University of Michigan.
} 
Section 3, we describe our data and sample criteria, and present descriptive statistics; in Section 4 we address potential selection issues that can affect the validity of our estimates; in Section 5 we estimate the effects of leaving active service in periods of high unemployment on education attainment and on marital status; in Section 6, we estimate the effects on employment and earnings using administrative Social Security data; in Section 7, we estimate the effects on prospective retirement wealth; in Section 8, we estimate the effects on working in old age and on claiming Social Security benefits, based on the information reported in the HRS; finally, Section 9 presents the conclusions of our study.

\section{The draft in America, 1915-1973}

After relying on military drafts throughout its history, the United States shifted slowly away from the draft in the 1970s. For all practical purposes, the draft ended in 1973 and since that period, the U.S. has recruited military personnel and maintained an all-volunteer force (AVF). ${ }^{4}$ The current AVF model involves selection into the military — some who apply to enlist are deemed ineligible due to low test scores, poor health, or other issues; at the same time, military service is relatively rare among the most advantaged members of society. Additionally, military service today is much more common among those whose parents served in the military (Schafer, 2017)

Prior to the advent of the AVF, a draft was enacted surrounding each of the major conflicts during the period 1915-1975 (in fact, the draft was also used in earlier periods; see Sohoni and Vafa (2010), as well as Barry (2013) for more information). At first glance, the draft

\footnotetext{
4 Although draft numbers were assigned through 1975 covering men born through 1956, no men were drafted into service after 1973. However, the Selective Service has continually required that all men register upon turning 18; this pool exists should a draft become necessary. See Rostker (2006) for a discussion of the transition and a complete history of the All-Volunteer Force in the United States.
} 
appears to avoid many selection issues, creating a situation in which enlistees could be viewed as a random sample of the population of young males. However, it is worth noting than even in different eras, some young men served in the military voluntarily. Thus, there might still be a selection into the military that varies across veterans of different eras. We explicitly address this in our analysis as discussed later. In the draft era, it is also worth noting that some young men are deemed ineligible to serve. This means that some of our results may lack external validity for the average male population. Below, we briefly describe the draft during each major conflict relevant to our data.

In World War II, about 16 million men served in the military: The overall population of the U.S. at the time was about 133 million. The WWII military experienced extremely rapid growth at the advent of the war, growing twenty-fold in three years. During this period, the majority of young men served in the military. At the end of the war, one might expect that all service members would have exited at around the same time (their commitment was for the length of the war plus six months). In fact, there is some variation in timing of exit. While there was significant public pressure to release service members quickly, it was not possible to process all service members simultaneously: Demobilization began in May 1945 and continued through 1946. During this period, the size of the military reduced by about 87 percent. Today, only about 10 percent of WW II veterans are living; thus, this group will likely not make up most of our sample, but because of the sheer size of the WW II military, they still form a relatively large subsample.

During the Korea conflict, some six million served; at least 1.5 million were drafted and many of the others were draft-induced volunteers. Terms of service were generally 24 months, 
allowing substantial variation of economic conditions at exit. About 2.3 million Korea-era veterans are alive today.

The Vietnam conflict was lengthy in nature. During that era, some 8.7 million service members served; about 3.4 million were deployed to Southeast Asia. Draftees generally served in the Army for 24 months; volunteers chose their branch and generally served for three years. Large numbers of men were drafted in 1970, 1971, and 1972. Thus, there is considerable variation in the timing of exit among those who were drafted and among draft-induced volunteers. At the end of the conflict, the size of the military decreased dramatically. Some 7.4 million veterans from this era are alive; these veterans make up a large proportion of today's veteran population.

Figure 1 traces out the size of the U.S. (active component) military end strength, as well as the population of young men (ages 19 to 22) and the ratio of the end strength to the young men. This figure shows the overall population growth during the period, as well as the dramatic changes in the size of the end strength between periods of conflict and peaceful periods. The ratio of end strength to young men was lowest during the period prior to WW II. Despite the relatively small population of the country during this period, the standing military was very small (the end strength in 1930 was about 250,000 compared to about 12 million at the peak of WW II and roughly 1.3 million in recent years). ${ }^{5}$ During WW II, the end strength was substantially larger than the population of young men (many who served were well outside the 19-22-year-old age range). During other periods included in Figure 1, the ratio of end strength to young men generally was below 1 . Immediately following WW II, the services drew down to the point that

\footnotetext{
5 The end strength in Figure 1 includes only those serving in the Active Components; the sizes of the Reserve Components also have fluctuated substantially over time although these components generally were less central to warfare efforts in the first half of the $20^{\text {th }}$ century.
} 
end strength dropped below two million. At this point, the population of young men was about three times the size of the end strength. In many of the years encompassing the Korean and Vietnam wars, the end strength remained above two million; the size of the force increased during each period of conflict and then returned to something closer to two million. The size of the force fell around the advent of the AVF, and the general trend has been downward since 1980 while the overall size of the U.S. population has increased. Today, the ratio of end strength to young men is about 0.15 , a ratio not seen since prior to WW II. ${ }^{6}$

Figure 1: Young men in the United States and the U.S. military end strength

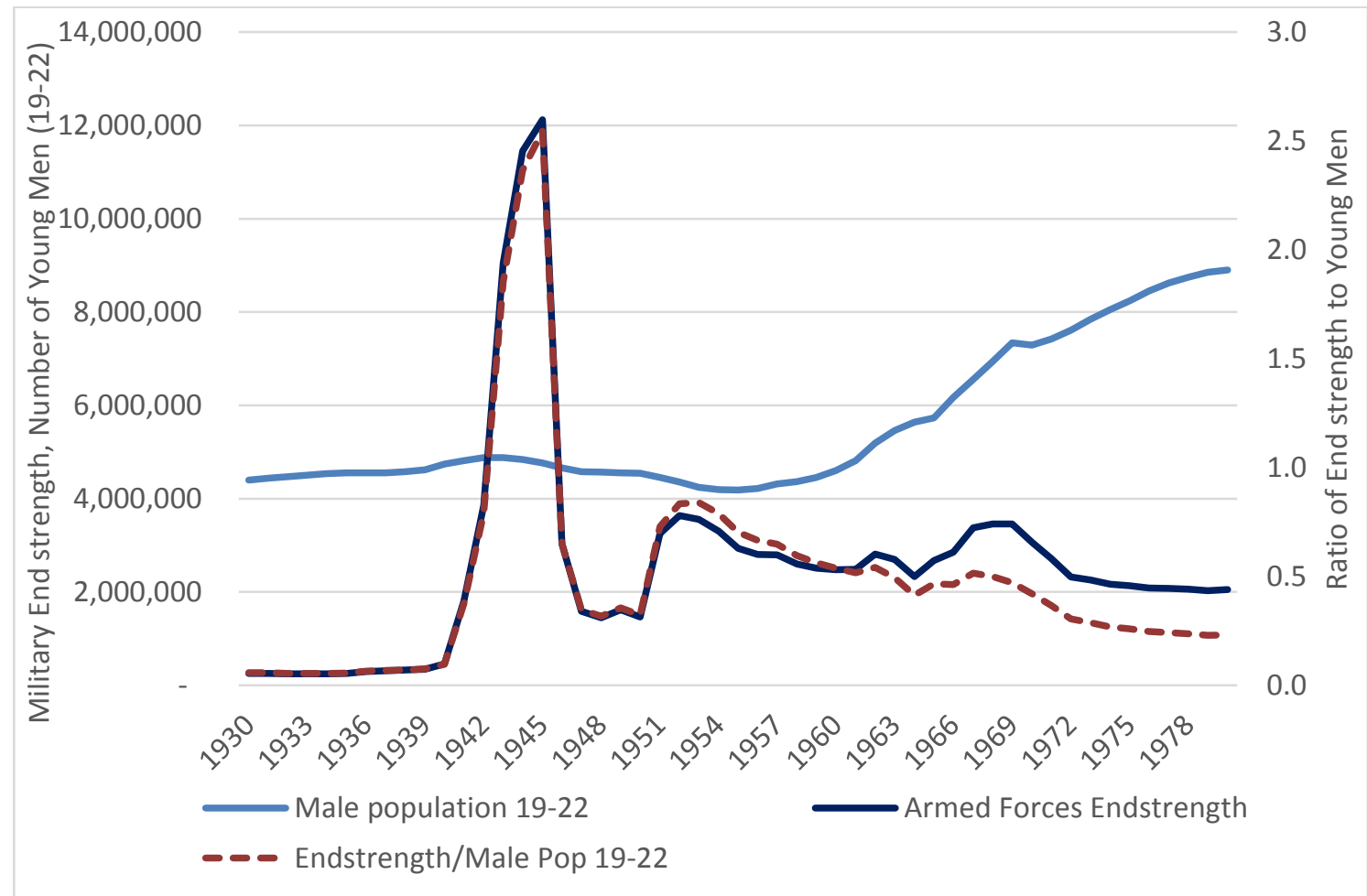

NOTES: Authors' tabulations based on Census data, Population Representation in the Military Services, various years; Selected Manpower Statistics, various years; Census data, various years.

\footnotetext{
6 Given the increasing military role filled by women, the ratio of end strength to the total youth population may be the more relevant metric. Today, that ratio is approximately 0.07 . By these measures, the probability of serving in the military today is markedly lower than it was during the eras included in Figure 1.
} 


\section{Data and Sample}

To determine the long-run effects of veterans' transitions into the labor force during weak and strong labor markets, we require a dataset covering a long period of time to allow us to follow veterans for multiple decades while also including a wide variety of economic conditions. Fortunately, the Health and Retirement Study (HRS) provides very long-term information on a sample of veterans who served during several different periods of time. About 20 percent of men ages 50 to 65 are veterans, and among men older than 50, veteran status is more common than college completion. ${ }^{7}$ Despite the recent conflicts, most veterans today are approaching or have passed retirement age; about one-third of male veterans are older than 70 and about threequarters are older than 50 . Therefore, it is not surprising that veterans are well represented in the HRS, which has information on a total of 7,579 male veterans.

In this study, we focus on male veterans who served only for a short period of time (less than five years) and that left active service at a relative young age (not older than 25). We also focus on veterans who enlisted no later than 1972, i.e. before the elimination of the draft and establishment of an all-volunteer force (AVF). There are about 4,507 male veterans in the HRS that fit our sampling criteria. Figure 2 shows the distribution of these veterans in the HRS by the year they exited active military service. It also shows the national unemployment rate that prevailed at the time they exited. Figure 2 shows that there is large variation in the unemployment rate even among veterans leaving the military in the same era, and that our sample includes veterans from several different eras.

\footnotetext{
7 Authors' calculations from the American Community Survey 2014. This data source indicates roughly 6.3-million male veterans ages 50 to 65 and nearly 15-million male veterans ages 50-plus in 2014, and these numbers accord well with various figures available from va.gov. In contrast, as of 2014 there were some 2.6-million post-9/11 era veterans (see va.gov).
} 
Figure 2: Number of veterans in the HRS, by year exited active service, and unemployment rate

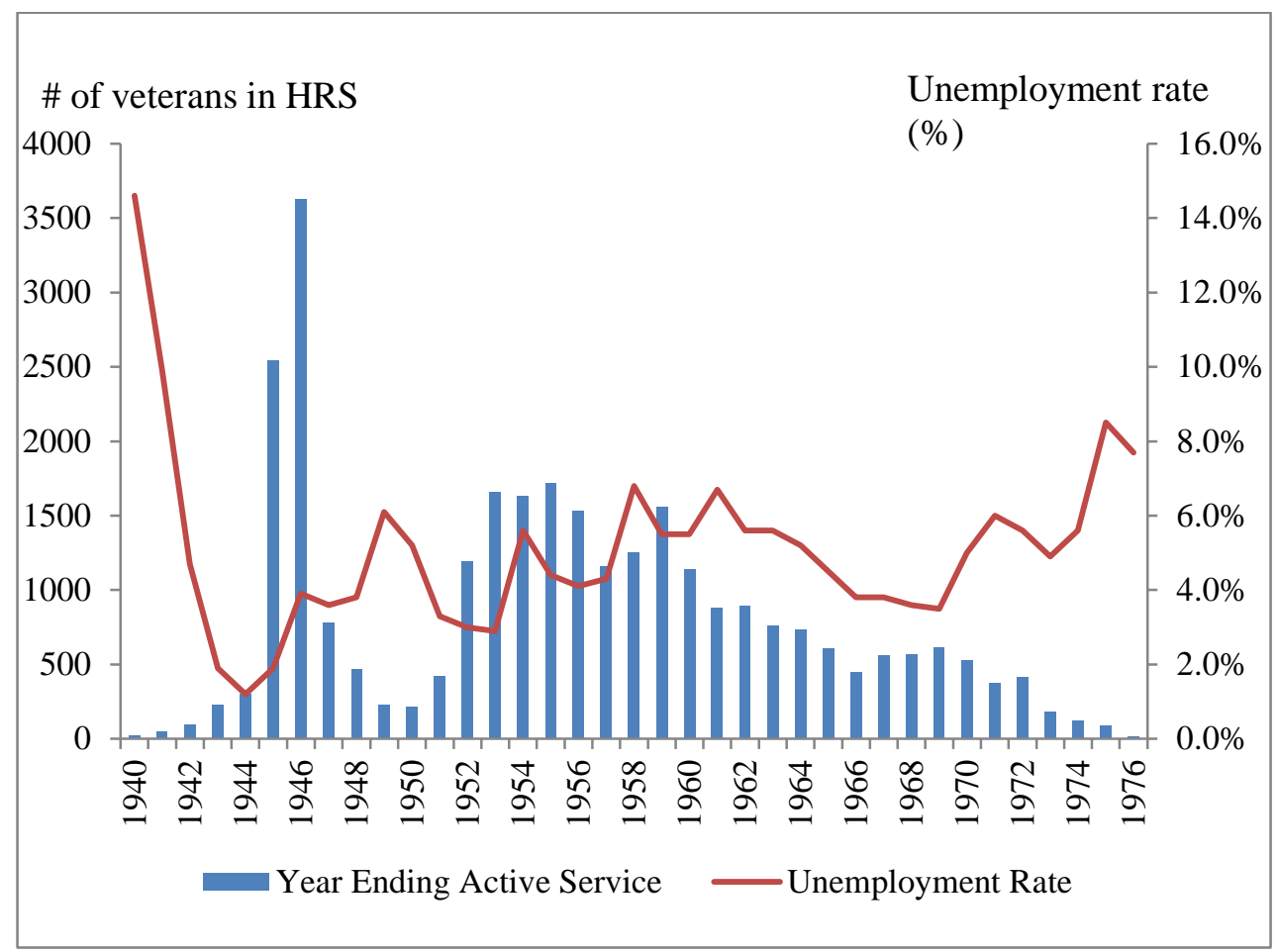

NOTES: Authors' Calculations based on HRS files (1992-2012) and Bureau of Labor Statistics data. Includes only veterans who served less than 5 years, enlisted in years up to 1972, and left active service at age 25 or younger. The data also contains 10 veterans who left active service across before 1940 (from 1929 to 1939). We have omitted them for ease of plotting the figure.

In addition to the HRS Core Files - which contain information on veteran status, the year enlisted in active service and the year exited military service — we also use the following datasets: i) the RAND HRS Data File, which contains variables harmonized across waves regarding employment status and several measures of household wealth; ii) the respondent crossyear SSA summary earnings file, which provides information on earnings from Social Security administrative data; iii) the cross-year prospective Social Security wealth measures of pre- 
retirees, available for 1992, 1998, 2004, and 2010 ; and the pension wealth data files from 1992 to $2010 .{ }^{8}$

Table A1 in the Appendix shows the sample descriptive statistics, based on all the person-year observations available in the data. There are 29,753 person-year observations for the veterans that fit our sample criteria. ${ }^{9}$ The average age in the sample is 67.8 years. The average age at enlistment was 19.6 years, and the average age at exit from military service was 22.1 years. For the average observation in the sample, active service ended 46.1 years ago. This highlights the potential of the HRS for studying the long-term effects of leaving military service in periods of a weak economy. The average prevailing unemployment rate at the time of exit from the military is 4.2 percent. The typical veteran in our sample is white (89.2 percent), with a high school degree or GED (89.1 percent), married (79.1 percent), and retired (55 percent).

Table 1A also provides descriptive statistics based on dividing the observations into three roughly equal groups by unemployment rate at the time of exit from the military. Table 1A indicates that veterans who left active service in periods of high unemployment are more likely to have some college education and more likely to be separated or divorced than those who left active service in periods of low unemployment. Veterans who left active service in periods of high unemployment are more likely to work full time, which may be partly or completely explained by the fact that they are also on average younger. (Thus, we control for age in our

\footnotetext{
8 The RAND HRS Data file is an easy to use longitudinal data set based on the HRS data. It was developed at RAND with funding from the National Institute on Aging and the Social Security Administration. The respondent cross-year SSA summary earnings file is a restricted-access dataset, available upon application from HRS. It includes earnings from Social Security administrative records for the period 1951 through 2013, for those HRS respondents who gave consent to access their Social Security information. The cross-year prospective Social Security wealth measures file is a public access dataset contributed by Kapinos et al. (2016) and Kapinos and Fang (2016).

The pension welath data files is a public access dataset contributed by Gustman, Steinmeier, and Tabatabai (2014). ${ }^{9}$ However, the sample size for each regression changes depending on the availability of the data as shown in the next sections.
} 
empirical analysis.) We do not see significant differences in terms of wealth for veterans who left active service in periods of low or high unemployment. But we see, counterintuitively, that veterans who left active service in periods of high unemployment have slighter higher earnings.

\section{Addressing potential selection issues}

\section{Selection into the military across eras}

Our analyses compare experiences of veterans who exited the military during relatively prosperous times with the experiences of those who exited during less prosperous times. This strategy would work if the selection into the military was somewhat consistent over the eras included in our data. However, there are reasons to think that this may not be the case. For example, Figure 1 suggests that during WW II a very large proportion of young men likely served in the military. In fact, during WW II, military service was the norm, except among those deemed ineligible to serve. Accordingly, Angrist and Krueger (1994) find that veterans from the WW II earn more than nonveterans due to a positive selection (in terms of their earnings potential) into the military. In contrast in the eras following WW II through Vietnam, a smaller and constant proportion of the population served in the military (although there was a sharp build-up at the beginning of each conflict and a drawdown at the end), and there is no evidence of a positive or negative selection into the military in the literature. ${ }^{10}$ This suggests that while the population of WW II veterans may differ from those of later eras, the veterans of the Korean and Vietnam eras may be comparable on many measures. As noted above, these veterans should make up most of our sample.

\footnotetext{
10 Note that among Vietnam-era white men, military service was associated with large wage penalties upon entering the civilian labor market. By the 1990s, however, wages were quite similar between those who served in the military and otherwise similar men who did not (see, in particular, Angrist (1990), as well as Angrist and Chen (2011)).
} 
To address the issue of differential selectivity into the military across eras, we control for sample selection, as in Heckman (1979), using two instruments to predict serving in the military. The first instrument is the average yearly ratio of the military end strength to the 19- to 22-yearold male population (Figure 1) during the years when a birth cohort was 19 to 22. We chose this range because 19 years is the average age of enlistment and 22 is the average age of leaving the military in our sample. Also, a similar age range has been used in previous research to predict the probability of enlistment (Card and Lemieux, 2001, De-Walque, 2007). As discussed in Section 2, the endstrengh-to-young-male-population ratio is driven by the U.S. conflicts rather than by individuals' decisions, offering a way to correct for the potential endogeneity of veteran status. The second instrument is the unemployment rate at age 19. Individuals may be more susceptible to join the military in periods of high unemployment, especially if they are more likely to be negatively affected by weak economic conditions. In this equation, we include both veterans and nonveterans from the HRS 1992-2012 waves.

Table 1 shows the estimation of the selection equation into military service (probit model, marginal effects reported). In addition of the two instruments discussed above, we also control for race. We do not control for other characteristics (such as education, marital status, etc.) since they are likely to be affected by the veteran status. We observe that both the Average End strength / Male 19-22 population ratio and the unemployment rate at age 19 are highly predictive of serving in the military. Using this equation, we predict for all veterans the Inverse Mills Ratio $\lambda(X \beta)=\phi(X \beta) / \Phi(X \beta)$, where $X \beta$ is the predicted Z-score, $\phi(\cdot)$ denotes the normal density function, and $\Phi(\cdot)$ denotes the normal distribution function. We include $\lambda(X \beta)$ as an additional control in all our regression models. 
Table 1: Selection equation into military service (probit model; marginal effects reported)

\begin{tabular}{lc}
\hline & $\begin{array}{c}\text { Outcome: } \\
\text { 0 = Nonveteran } \\
\text { 1= Veteran }\end{array}$ \\
\hline Average End strength / Male 19-22 population & $0.398^{* * *}$ \\
& $(0.012)$ \\
Unemployment rate at age 19 (in percentage points) & $0.007^{* * *}$ \\
Race (Omitted category: White) & $(0.002)$ \\
Black & $-0.109^{* * *}$ \\
Other & $(0.011)$ \\
Observations & $-0.244^{* * *}$ \\
& $(0.014)$ \\
Notes: Includes only one observation per male respondent in the HRS (after pooling waves $1992-$ & 14,004 \\
2012). Standard errors in parentheses. ${ }^{* * *}$ denotes $p$-value $<0.01,{ }^{* *}$ denotes $p$-value<0.05,
\end{tabular}

\section{Timing the exit from military service and potential measurement error}

Although former draftees/volunteers generally had few options to extend their service after the ends of their contracts, it is still possible that some could time their exit in response to weak civilian labor markets. To address this potential source of endogeneity, we instrument the unemployment rate in the year of exit from active service with the average unemployment rate in years two and three after enlistment. We choose this average because the two most common contract durations in the draft area were two and three years (see Section 2). In fact in our sample, 35.6 percent of veterans have a calculated duration of service of two years and 26.7 percent have a calculated duration of three years (15.9 percent have a calculated duration of one year or shorter, and 21.7 percent have a calculated duration of four years). It is worth noting that respondents report the year they enlisted and the year they left active service, so there is some noise (rounding) in the calculation of total years of service. 
As expected, the average unemployment rate in years two to three after enlistment is a strong instrument for the unemployment in the year of exit from active service. Table A2 in the Appendix shows the first stage regression from the estimation of the effects on educational attainment (see next section). Shea's adjusted partial $R^{2}$ (Shea, 1997) is a useful statistic in cases with more than one endogenous regressor, as is the case for many regressions in this paper. Thus, instead of the F-statistic, we will discuss the Shea's adjusted partial $R^{2}$, presenting in each table the lowest Shea's adjusted partial $R^{2}$ across all endogenous regressors. ${ }^{11}$ In the case of Table A2, the Shea's adjusted partial $R^{2}$ is large $(0.4345)$, indicating that there is not a problem of weak instruments. $^{12}$

Besides controlling for potential timing in the decision to leave military service, the instrumental variable approach can also help overcome issues of measurement error. As discussed above, the most common duration in contracts should be two and three years old. A veteran reporting a duration of four years of service, for instance, might indicate that he extended his service, but could also indicate a misreport of the year leaving active service in the HRS considering that veterans report this information many years after they left service. By using the average unemployment rate of the two most expected contract durations as an instrument we are also able to attenuate this source of measurement error in the data.

\section{Effect on educational attainment and marital status}

Our primary interest is the long-term effects of the unemployment rate at the time of reintegration into the civilian economy on earnings, wealth, and retirement among veterans of

\footnotetext{
11 For completeness, we note that the F-statistic associated with this instrument is quite large (3408.77).

12 Shea's adjusted partial $R^{2}$ are calculated using the command estat firststage after the ivregress command in STATA 13 (StataCorp, 2013).
} 
the draft era. However, the literature suggests that individuals may respond to the lack of opportunities in a weak labor market by acquiring more schooling. Table $1 \mathrm{~A}$ in the Appendix suggests that veterans who entered the civilian labor market in periods of high unemployment are slightly more likely to complete at least some college. Therefore, we start by investigating the effect on educational attainment of the unemployment rate at the time of exit from active service.

For each potential educational attainment category, we estimated the following linear probability model, where the subscript $i$ indexes veterans:

$$
Y_{i}=\alpha+\beta_{U R} U R_{i}+\beta_{\mathrm{X}} X_{i}+\epsilon_{i}
$$

For each veteran, we used his first observation available in the HRS. The variable $Y_{i}$ is an indicator variable that equals 1 if the veteran has the education level of interest, or equals 0 otherwise. The variable $U R_{i}$ is the prevailing unemployment rate at the time of leaving active service. The vector $X_{i}$ contains other controls including, race, age at exit from active service, whether the respondent has a disability related to active service, and the Inverse Mills Ratio to control for selectivity into veteran status. The coefficients $\beta_{U R}$ estimated (separately) for each educational attainment category are shown in Table 2, using ordinary least squares (OLS) and two-stage least squares (2SLS)

Our estimations indicate that the veterans who left military service in periods of high unemployment were more likely than others to continue their education. We find positive and significant effects of the unemployment rate on the probabilities of having some college education and of having a college degree or higher education; and negative and significant effects on the probability of not having a high school degree (or GED). The effects are not small. For example, we find that a 1-percentage-point increase in the unemployment rate in the year the veteran entered civilian life increases the probability of having a college degree by 1.4 
percentage points in the OLS model, and by 3.0 percentage points in the 2SLS model (roughly 20 percent compared to the mean). It is noteworthy that veterans during the eras covered in the HRS generally had access to education benefits upon leaving active duty. A similar behavioral response regarding college enrollment was found for individuals graduating from high school in period of high unemployment by Arkes (2003) and by Hershbein (2012). The larger estimates in the 2SLS specification could reflect that some veterans may have had some opportunities to time their exit from active service, but it might also reflect a correction for measurement error. We are not able to distinguish between these potential explanations in our analysis.

We also find that exiting the military in a period of high unemployment affects veteran's marital status in the long-run. We estimated OLS and 2SLS regressions similar to equation (1), but for marital status (each category of marital status is the dependent variable in a separate regression). The estimated results are shown in Table 3.

Table 2: Unemployment rate at exit from active service and educational attainment

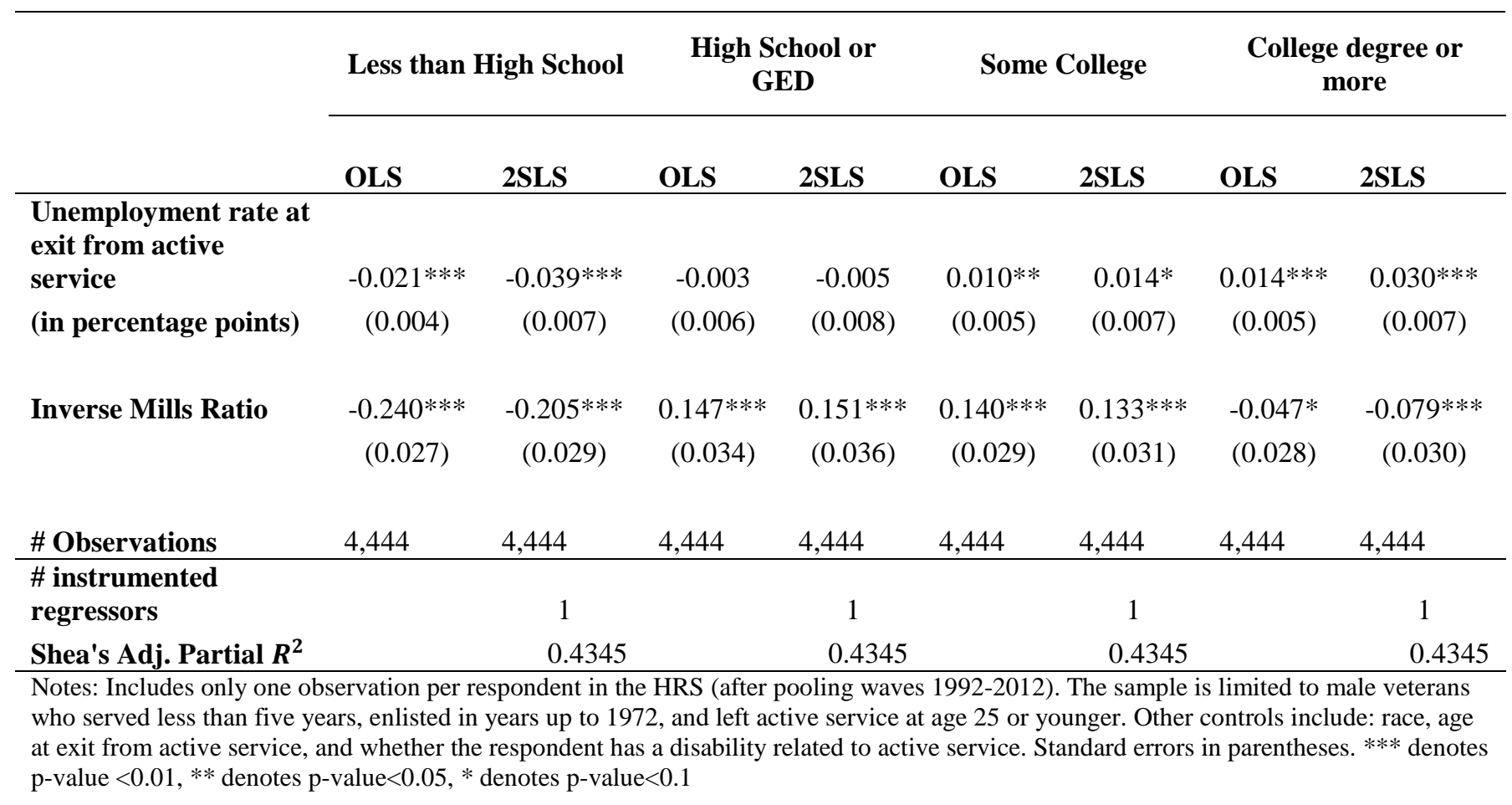


Table 3: Unemployment rate at exit from active service and marital status

\begin{tabular}{|c|c|c|c|c|c|c|c|c|}
\hline & \multicolumn{2}{|c|}{ Married } & \multicolumn{2}{|c|}{$\begin{array}{l}\text { Separated or } \\
\text { Divorced }\end{array}$} & \multicolumn{2}{|c|}{ Widowed } & \multicolumn{2}{|c|}{ Never Married } \\
\hline & OLS & 2SLS & OLS & 2SLS & OLS & 2SLS & OLS & 2SLS \\
\hline $\begin{array}{l}\text { Unemployment rate at } \\
\text { exit from active } \\
\text { service } \\
\text { (in percentage points) }\end{array}$ & $\begin{array}{c}-0.027^{* * *} \\
(0.005)\end{array}$ & $\begin{array}{c}-0.024^{* * *} \\
(0.008)\end{array}$ & $\begin{array}{c}0.019 * * * \\
(0.004)\end{array}$ & $\begin{array}{c}0.017^{* * * *} \\
(0.006)\end{array}$ & $\begin{array}{c}0.008 * * * \\
(0.002)\end{array}$ & $\begin{array}{c}0.005 \\
(0.004)\end{array}$ & $\begin{array}{c}0.001 \\
(0.002)\end{array}$ & $\begin{array}{c}0.004 \\
(0.004)\end{array}$ \\
\hline Inverse Mills Ratio & $\begin{array}{l}-0.004 \\
(0.031)\end{array}$ & $\begin{array}{l}-0.004 \\
(0.031)\end{array}$ & $\begin{array}{c}0.039 \\
(0.024)\end{array}$ & $\begin{array}{l}0.040 * \\
(0.024)\end{array}$ & $\begin{array}{c}-0.035^{* *} \\
(0.016)\end{array}$ & $\begin{array}{c}-0.035^{* *} \\
(0.016)\end{array}$ & $\begin{array}{c}0.007 \\
(0.014)\end{array}$ & $\begin{array}{c}0.006 \\
(0.014)\end{array}$ \\
\hline \# Observations & 4,441 & 4,441 & 4,441 & 4,441 & 4,441 & 4,441 & 4,441 & 4,441 \\
\hline $\begin{array}{l}\text { \# instrumented } \\
\text { regressors }\end{array}$ & & 1 & & 1 & & 1 & & 1 \\
\hline Shea's Adj. Partial $R^{2}$. & & 0.337 & & 0.337 & & 0.337 & & 0.337 \\
\hline
\end{tabular}

Our OLS estimations indicate that 1-percentage-point increase in the unemployment rate in the year of exit from active service is associated with a 2.7-percentage-point reduction in the probability of being married, and a 1.7-percentage-point increase in the probability of being divorced or separated. The effect sizes are quite similar in the 2SLS models. We do not find an effect on the probability of never being married. Thus, our findings suggest that veterans who entered the civilian labor market in periods of high unemployment suffer higher levels of family instability. Previous investigations on the effect of entering the labor market during weak economic conditions have neglected to study its effect on marriage and family stability. ${ }^{13}$

In the next sections, we investigate the effect of reentering civilian life in years of high unemployment on earnings, wealth and retirement decisions. In these analyses, we do not control

\footnotetext{
13 However, our findings are supported by a related literature that links the decline in the prevalence of marriage among young adults to reduced labor-market opportunities faced by males, which make them less valuable as marital partners (Autor, Dorn, and Hanson, 2017).
} 
for educational attainment or marital status because they are also affected by the notional experiment at hand. Moreover, they are important determinants of earnings, wealth, and retirement decisions. Thus, controlling for education and marital status would bias our estimates of the average total effect of reentering the civilian life in periods of high unemployment. ${ }^{14}$

\section{Effect on employment and earnings}

We estimate the short-term and long-term effects of reentering the civilian labor market in periods of high unemployment using information from the respondent cross-year SSA summary earnings file, in combination with the RAND HRS datafiles. Figure 3 shows the average earnings in 2016 dollars of the veterans in our sample after they left active service. We observe that average earnings tend to decline, mainly due to reduction in the probability of receiving income, roughly 30 years after leaving active service — the average veteran in our sample would be 52 years old at that point. Our regression analysis takes into account this shape of the earnings profile by accommodating a flexible form in the estimation of the short- and long-run effects on employment and earnings of the unemployment rate at the time of exit from active service.

\footnotetext{
14 In other words in this case, educational attainment and marital status are "bad controls" (Angrist and Pischke, 2008).
} 
Figure 3: Earnings profile of veterans after exit from active service

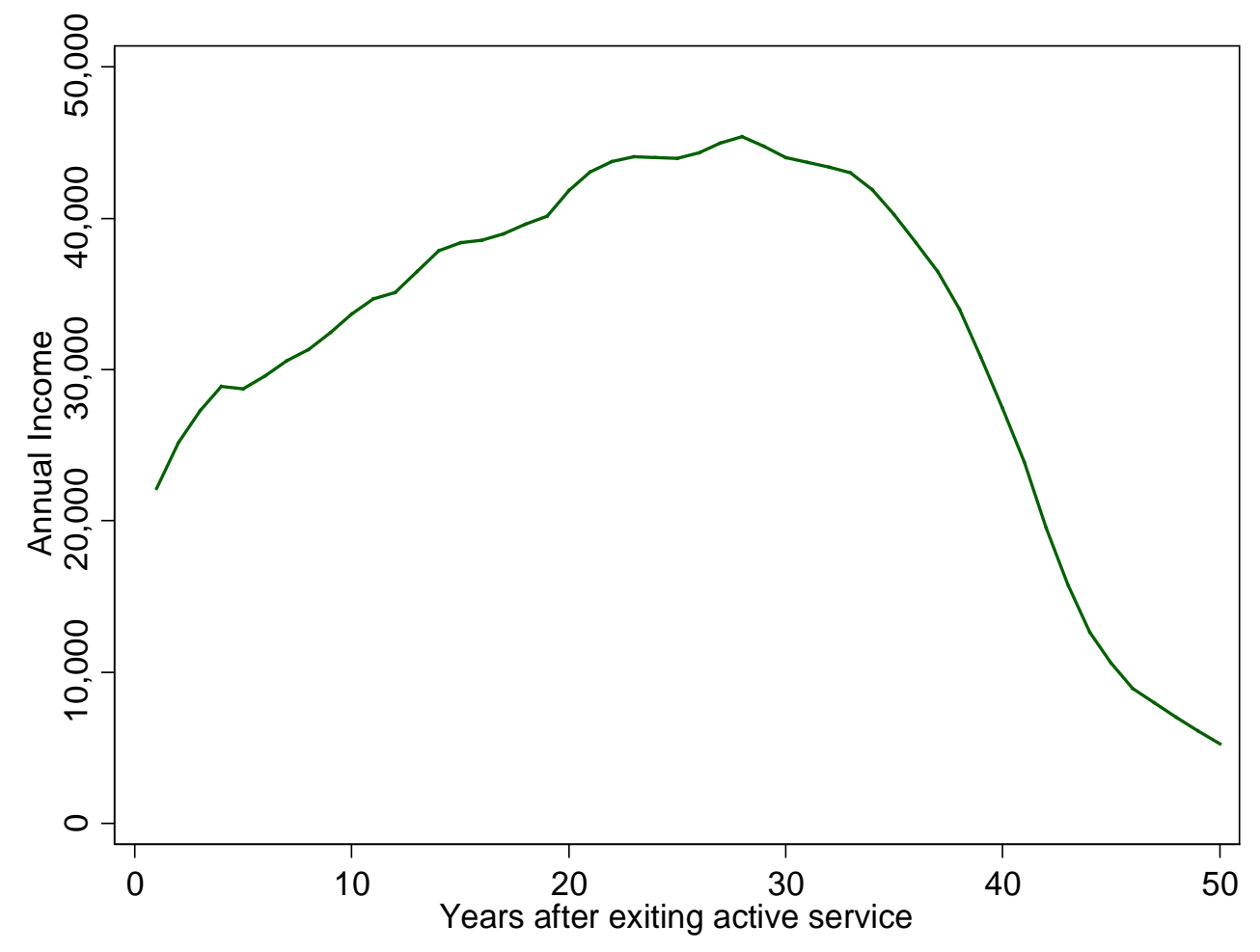

Source: RAND HRS files and Respondent Cross-Year SSA Summary Earnings File.

Note: The sample is limited to male veterans who served less than five years, enlisted in years up to 1972, and left active service at age 25 or younger.

First, we estimate the linear probability model shown in equation (2) below. The outcome $Y_{i t}$ is an indicator variable measuring whether veteran $i$ is working in year $t$. We use two definitions for $Y_{i t}:$ i) whether the veteran earns income in every quarter in year $t$; and ii) whether the veteran earns no income (in any quarter) in year $t$.

$$
Y_{i t}=\sum_{k=1}^{10} \beta_{T, k} \text { Time }_{k, i t}+\sum_{k=1}^{10} \beta_{U R, k}\left(\text { Time }_{k, i t} \times U R_{i}\right)+\beta_{X} X_{i}+\gamma_{t}+\epsilon_{i t}
$$

On the right-hand side of equation (2), $U R_{i}$ is the unemployment rate at the time of exit from active service and Time $_{k, i t}$ are a set of indicator variables for the number of years passed since leaving active service. We only include in the regression the years after the veteran left the military (up to 50 years). We have grouped the time passed in periods of five years. The 
coefficients of interest are $\beta_{U R, k}$. Additional controls in $X_{i}$ include race, age at exit from active service, whether the respondent has a disability related to active service, and the Inverse Mills Ratio to control for selectivity into veteran status. We also control for year fixed effects $\left(\gamma_{t}\right)$ in the regression. All standard errors are clustered at the individual level.

The estimation results for $\beta_{U R, k}$ are shown in Table 4. In the 2SLS model we instrument Time $_{k, i t} \times U R_{i}$ with Time $_{k, i t} \times \overline{U R_{l}}$, where $\overline{U R_{l}}$ is the average unemployment rate two to three years after enlistment. There are in total 10 instrumented variables. ${ }^{15}$ We find that higher unemployment rates are associated with a lower initial probability of reporting income in all quarters, although the effects are not statistically significant. Interestingly, these negative effects reverse in the long-run, and even turn positive and significant 40 years after leaving active service (i.e., when the average veteran is 62 years old). For example, the 2SLS model indicates that 1-percentage-point higher unemployment rate at the time of exit from active service increases the probability of reporting income in all quarters by 4.1 percentage points 41 to 45 years after leaving active service. This suggests that veterans leaving service in periods of weak labor markets are likely to retire later. We return to this issue later.

Table 4 also indicates that veterans leaving active service in periods of high unemployment are more likely to not report income in any quarter in the first years after exit from service (these estimates generally do not achieve statistical significance), but this effect again is reversed in the latter years, in line with the previous finding.

\footnotetext{
15 The lowest Shea's partial $R^{2}$ is still relatively large, indicating that there is not a problem of weak instruments.
} 
Table 4: Unemployment rate at exit from active service and employment

Income in all quarters

OLS

2SLS

No Income in any quarter

\begin{tabular}{|c|c|c|c|c|}
\hline & OLS & 2SLS & OLS & 2SLS \\
\hline \multicolumn{5}{|l|}{$\begin{array}{l}\text { Average effect of unemp.t } \\
\text { rate at exit from active } \\
\text { service: }\end{array}$} \\
\hline \multirow[t]{2}{*}{ 1-5 years after exit } & -0.002 & -0.003 & 0.003 & -0.004 \\
\hline & $(0.006)$ & $(0.011)$ & $(0.004)$ & $(0.008)$ \\
\hline \multirow[t]{2}{*}{ 6-10 years after exit } & -0.003 & -0.011 & 0.002 & 0.004 \\
\hline & $(0.005)$ & $(0.009)$ & $(0.004)$ & $(0.007)$ \\
\hline \multirow[t]{2}{*}{ 11-15 years after exit } & $-0.014^{* * *}$ & $-0.022 * *$ & $0.007^{*}$ & 0.009 \\
\hline & $(0.005)$ & $(0.008)$ & $(0.004)$ & $(0.007)$ \\
\hline \multirow[t]{2}{*}{$16-20$ years after exit } & $-0.009 *$ & -0.012 & $0.008^{*}$ & 0.009 \\
\hline & $(0.005)$ & $(0.008)$ & $(0.004)$ & $(0.007)$ \\
\hline \multirow[t]{2}{*}{ 21-25 years after exit } & -0.005 & -0.006 & 0.006 & 0.006 \\
\hline & $(0.005)$ & $(0.008)$ & $(0.004)$ & $(0.008)$ \\
\hline \multirow[t]{2}{*}{ 26-30 years after exit } & -0.003 & -0.004 & 0.003 & 0.004 \\
\hline & $(0.005)$ & $(0.008)$ & $(0.005)$ & $(0.008)$ \\
\hline \multirow[t]{2}{*}{ 31-35 years after exit } & -0.002 & -0.004 & 0.001 & 0.004 \\
\hline & $(0.005)$ & $(0.009)$ & $(0.005)$ & $(0.009)$ \\
\hline \multirow[t]{2}{*}{$36-40$ years after exit } & 0.005 & 0.015 & -0.004 & -0.014 \\
\hline & $(0.006)$ & $(0.010)$ & $(0.006)$ & $(0.010)$ \\
\hline \multirow[t]{2}{*}{ 41-45 years after exit } & $0.015^{* *}$ & $0.041^{* * *}$ & $-0.015 * *$ & $-0.041^{* * *}$ \\
\hline & $(0.007)$ & $(0.011)$ & $(0.007)$ & $(0.011)$ \\
\hline \multirow[t]{2}{*}{ 46-50 years after exit } & $0.020 * * *$ & $0.031^{* * *}$ & $-0.017 * *$ & $-0.028 * *$ \\
\hline & $(0.007)$ & $(0.012)$ & $(0.008)$ & $(0.012)$ \\
\hline \multirow[t]{2}{*}{ Inverse Mills Ratio } & 0.013 & 0.012 & 0.001 & 0.001 \\
\hline & $(0.025)$ & $(0.025)$ & $(0.023)$ & $(0.023)$ \\
\hline Observations & 146,951 & 146,951 & 146,951 & 146,951 \\
\hline \multirow{3}{*}{$\begin{array}{l}\text { \# instrumented regressors } \\
\text { Lowest Shea's Adj. Partial } \\
R^{2} \text {. }\end{array}$} & & 10 & & 10 \\
\hline & & & & \\
\hline & & 0.334 & & 0.334 \\
\hline \multicolumn{5}{|c|}{$\begin{array}{l}\text { Notes: Includes only one observation per respondent in the HRS (after pooling waves 1992-2012). The } \\
\text { sample is limited to male veterans who served less than five years, enlisted in years up to } 1972 \text {, and left } \\
\text { active service at age } 25 \text { or younger. Other controls include: indicator variables for the number of years } \\
\text { passed since leaving active service, race, age at exit from active service, whether the respondent has a } \\
\text { disability related to active service, and year fixed effects. Standard errors (in parentheses) are clustered at } \\
\text { the individual level. }{ }^{* * *} \text { denotes p-value }<0.01, * * \text { denotes p-value }<0.05, * \text { denotes p-value }<0.1\end{array}$} \\
\hline
\end{tabular}


Now we turn to estimating the effects on earnings. We estimate an equation similar to equation (2), but the left-hand side variable $Y_{i t}$ is now a transformation of the earnings in each year. In particular, we use the hyperbolic sine transformation: $Y_{i t}=\log \left(E_{i t}+\sqrt{E_{i t}^{2}+1}\right)$, where is the $E_{i t}$ is the total earnings in year $t$. This transformation has several advantages. First, the function can take arguments that have negative, zero, and positive values. Thus, we can use the function not only with variables like earnings that can take the value of zero, but also with variables like net worth (as in Section 7) that can take negative values. Second, the hyperbolic sine transformation is symmetric around zero (see Figure A1 in the appendix). For example, the transformation applied to 1 gives 0.383 and applied to -1 gives -0.383 . This implies that, except for very low values in the argument, the inverse hyperbolic sine transformation can be approximated by $\log \left(2 E_{i t}\right)$ or $\log (2)+\log \left(E_{i t}\right)$ if the argument is positive; or by $-\log \left(2\left(-E_{i t}\right)\right)$ or $-\log (2)-\log \left(-E_{i t}\right)$ if the argument is negative. In both cases, the results can be interpreted the same way as using a standard logarithmic dependent variable. For example, using the OLS results in column 1 of Table 5, we find that 1-percentage-point increase in the unemployment rate at the time of exiting active service implies earnings that are, on average, 6.2 percent lower during the first five years, although the effect is not statistically significant. We found similar results (and nonsignificance) in the 2SLS model in column 2. Although most of the estimates in columns 1 and 2 in Table 5 for the first years after leaving active service are negative and nonsignificant, we see an overall trend of recovery. Figure 4 plots the estimates from the 2SLS model in column 2. Another interesting result is that we find positive effects on earnings about 40 years after exiting active service. This is explained, in part, by the fact that veterans leaving active service in weaker economic times appear to have longer working careers. 
In columns 3 and 4 of Table 5, we investigate how the unemployment rate at the time of leaving active service impacted earnings conditional on employment (i.e. the amount earned, conditional on reporting any earnings). To do this we selected only observations where earnings were reported for all quarters in the year. We find that a 1 percentage point increase in the unemployment rate at the time of leaving active service reduces earnings by 2.4 percent on average during the first five-year period using the OLS model and by 5.8 percent using the 2SLS model. The negative initial impact disappears with time, and it is not significant 15 years after leaving active service (the estimates from the 2SLS model are plotted in Figure 5). Columns 3 and 4 of Table 5 also show positive impacts on earnings 40 years after leaving the military, but the effects are not statistically significant. This suggests that an important factor behind the positive and significant effects found in columns 1 and 2 is the extensive margin, i.e., the probability of reporting income. We return later to the analysis of the effect of the unemployment rate at the moment of leaving active service on working and retiring in old age. 
Table 5: Unemployment rate at exit from active service and earnings

\begin{tabular}{|c|c|c|c|c|}
\hline & \multicolumn{2}{|c|}{ All observations } & \multicolumn{2}{|c|}{$\begin{array}{l}\text { With earnings in all } \\
\text { quarters }\end{array}$} \\
\hline & OLS & 2SLS & OLS & 2SLS \\
\hline \multicolumn{5}{|c|}{ Average effect of unemp.t rate at exit from active service: } \\
\hline $1-5$ years after exit & $\begin{array}{l}-0.062 \\
(0.050)\end{array}$ & $\begin{array}{l}-0.046 \\
(0.092)\end{array}$ & $\begin{array}{c}-0.024 * * * \\
(0.007)\end{array}$ & $\begin{array}{c}-0.058 * * * \\
(0.011)\end{array}$ \\
\hline 6-10 years after exit & $\begin{array}{l}-0.067 \\
(0.047)\end{array}$ & $\begin{array}{l}-0.151^{*} \\
(0.086)\end{array}$ & $\begin{array}{c}-0.014^{* *} \\
(0.006)\end{array}$ & $\begin{array}{c}-0.044^{* * *} \\
(0.010)\end{array}$ \\
\hline 11-15 years after exit & $\begin{array}{l}-0.091 * \\
(0.046)\end{array}$ & $\begin{array}{l}-0.111 \\
(0.083)\end{array}$ & $\begin{array}{c}-0.013^{* *} \\
(0.006)\end{array}$ & $\begin{array}{c}-0.028^{* * *} \\
(0.010)\end{array}$ \\
\hline $16-20$ years after exit & $\begin{array}{l}-0.093^{*} \\
(0.048)\end{array}$ & $\begin{array}{l}-0.083 \\
(0.083)\end{array}$ & $\begin{array}{l}-0.007 \\
(0.006)\end{array}$ & $\begin{array}{c}-0.006 \\
(0.011)\end{array}$ \\
\hline 21-25 years after exit & $\begin{array}{l}-0.063 \\
(0.051)\end{array}$ & $\begin{array}{l}-0.044 \\
(0.088)\end{array}$ & $\begin{array}{l}-0.005 \\
(0.007)\end{array}$ & $\begin{array}{l}-0.003 \\
(0.012)\end{array}$ \\
\hline 26-30 years after exit & $\begin{array}{l}-0.027 \\
(0.053)\end{array}$ & $\begin{array}{l}-0.022 \\
(0.091)\end{array}$ & $\begin{array}{c}0.001 \\
(0.008)\end{array}$ & $\begin{array}{c}0.008 \\
(0.013)\end{array}$ \\
\hline 31-35 years after exit & $\begin{array}{l}-0.017 \\
(0.059)\end{array}$ & $\begin{array}{l}-0.033 \\
(0.101)\end{array}$ & $\begin{array}{l}-0.009 \\
(0.009)\end{array}$ & $\begin{array}{c}0.003 \\
(0.015)\end{array}$ \\
\hline $36-40$ years after exit & $\begin{array}{c}0.057 \\
(0.068)\end{array}$ & $\begin{array}{c}0.199 * \\
(0.112)\end{array}$ & $\begin{array}{l}-0.000 \\
(0.011)\end{array}$ & $\begin{array}{c}0.018 \\
(0.018)\end{array}$ \\
\hline 41-45 years after exit & $\begin{array}{c}0.189 * * \\
(0.076)\end{array}$ & $\begin{array}{c}0.501^{* * *} \\
(0.122)\end{array}$ & $\begin{array}{c}0.004 \\
(0.017)\end{array}$ & $\begin{array}{l}0.045^{*} \\
(0.025)\end{array}$ \\
\hline 46-50 years after exit & $\begin{array}{c}0.196 * * \\
(0.081)\end{array}$ & $\begin{array}{c}0.338^{* * *} \\
(0.131)\end{array}$ & $\begin{array}{l}0.037 * \\
(0.022)\end{array}$ & $\begin{array}{l}0.066 * \\
(0.036)\end{array}$ \\
\hline Inverse Mills Ratio & $\begin{array}{c}0.068 \\
(0.268)\end{array}$ & $\begin{array}{c}0.057 \\
(0.268)\end{array}$ & $\begin{array}{c}0.040 \\
(0.032)\end{array}$ & $\begin{array}{c}0.032 \\
(0.032)\end{array}$ \\
\hline Observations & 146,581 & 146,581 & 146,581 & 146,581 \\
\hline $\begin{array}{l}\text { \# instrumented regressors } \\
\text { Lowest Shea's Adj. Partial } \\
R^{2} \text {. }\end{array}$ & & 0.335 & & 0.335 \\
\hline
\end{tabular}

Notes: Includes only one observation per respondent in the HRS (after pooling waves 19922012). The sample is limited to male veterans who served less than five years, enlisted in years up to 1972, and left active service at age 25 or younger. Other controls include: indicator variables for the number of years passed since leaving active service, race, age at exit from active service, whether the respondent has a disability related to active service and year fixed effects. Standard errors (in parentheses) are clustered at the individual level. *** denotes pvalue $<0.01, * *$ denotes $\mathrm{p}$-value $<0.05, *$ denotes $\mathrm{p}$-value $<0.1$ 
Figure 4: Effect of unemployment rate at exit from active aervice on earnings (all observations)

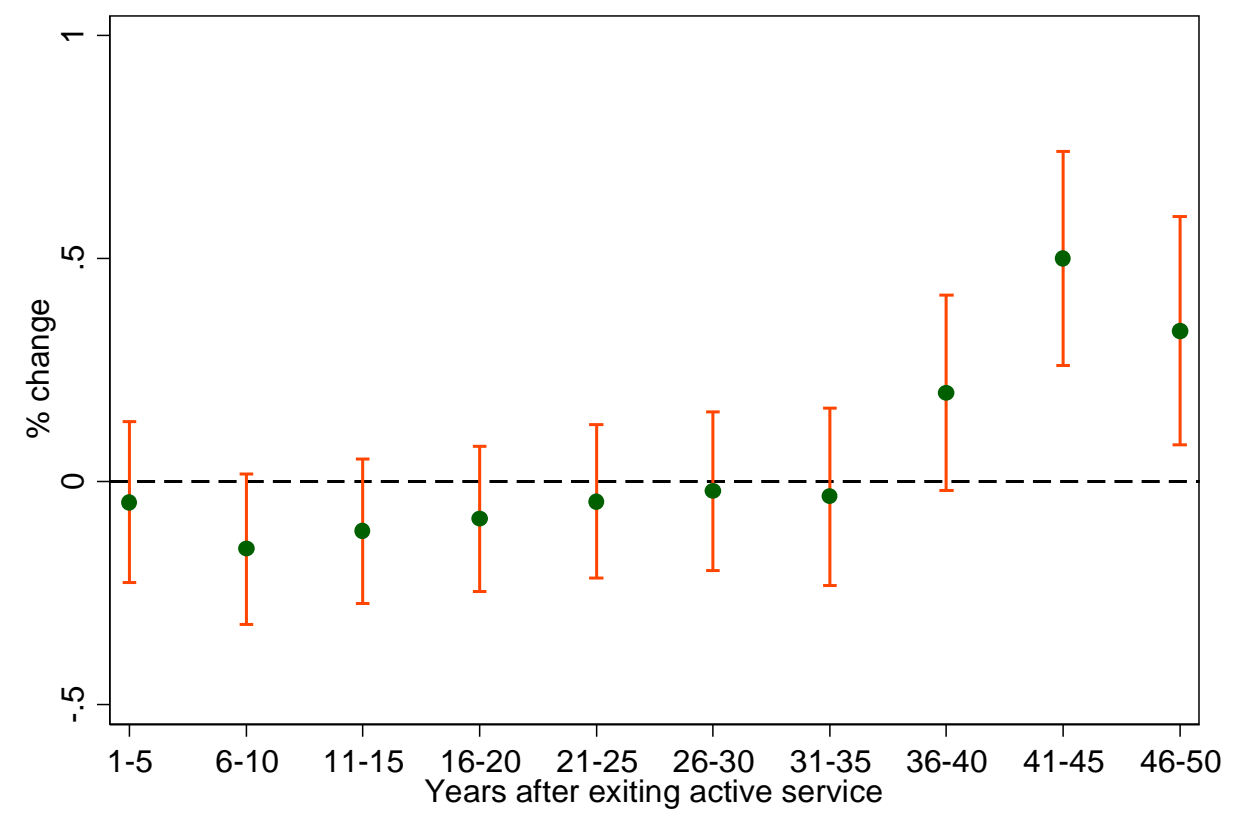

Note: 10 endogenous regressors. Lowest Shea's Adjusted Partial R-squared: 0.3351

Figure 5: Effect of enemployment rate at exit from active service on earnings (only observations with income in all quarters)

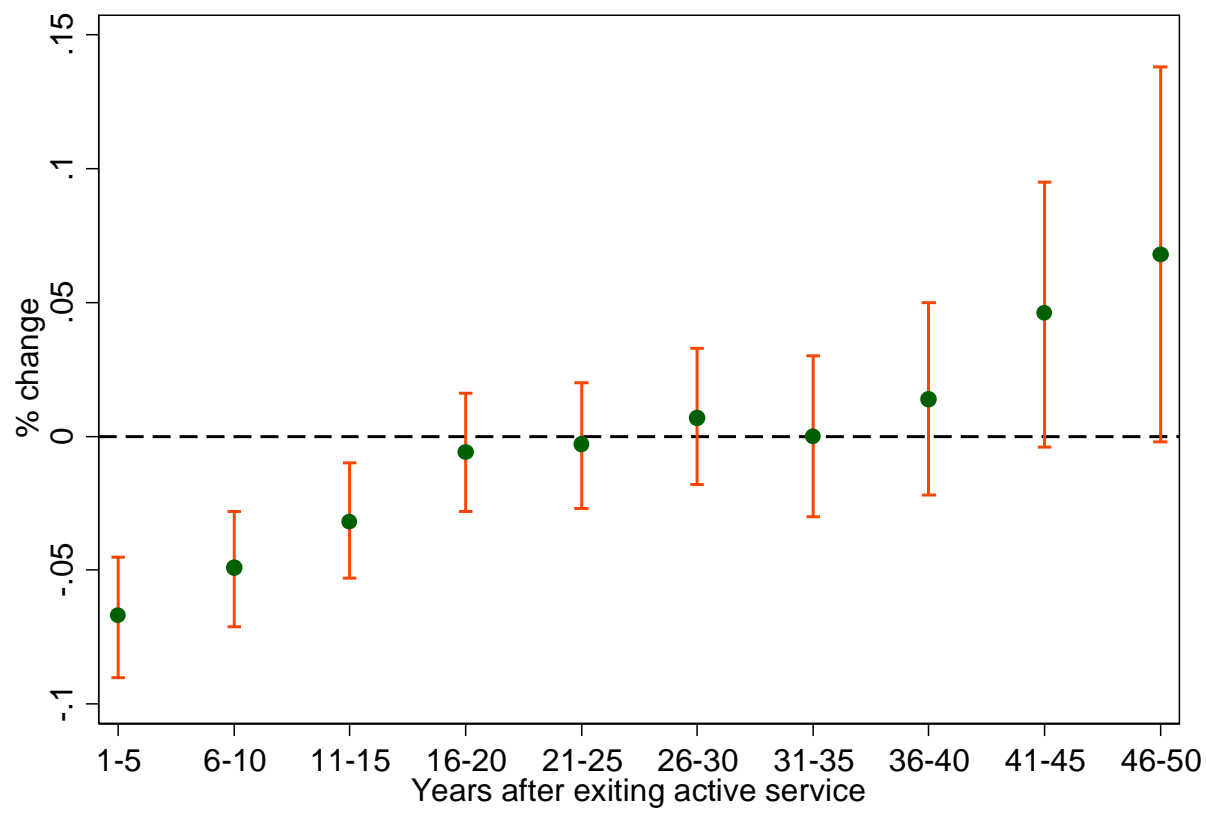

Note: 10 endogenous regressors. Lowest Shea's Adjusted Partial R-squared: 0.3618 


\section{Effect on prospective retirement wealth}

In the previous section, we found some evidence that the unemployment rate at the time of exit from the military had negative effects on earnings in the civilian labor market, especially after conditioning on receiving earnings (in all quarters) in a year. Since these effects lasted for more than a decade, we also investigate how the unemployment rate at the time of exit from the military influenced accumulated wealth and financial preparedness for retirement. Figure 6 shows the mean and median wealth of veterans in our sample, between the ages of 60 and 62 , broken out by wealth component. It excludes spouses’ prospective Social Security wealth and wealth from spouses’ employer-sponsored pension plans. Our analysis focuses on the largest components of the prospective retirement wealth: Social Security, employer pensions, housing (primary residency), and net financial worth (includes savings and financial investments in stocks, bonds, etc.). 
Figure 6: Prospective retirement wealth of male draft-era veterans in the HRS (2016 \$)

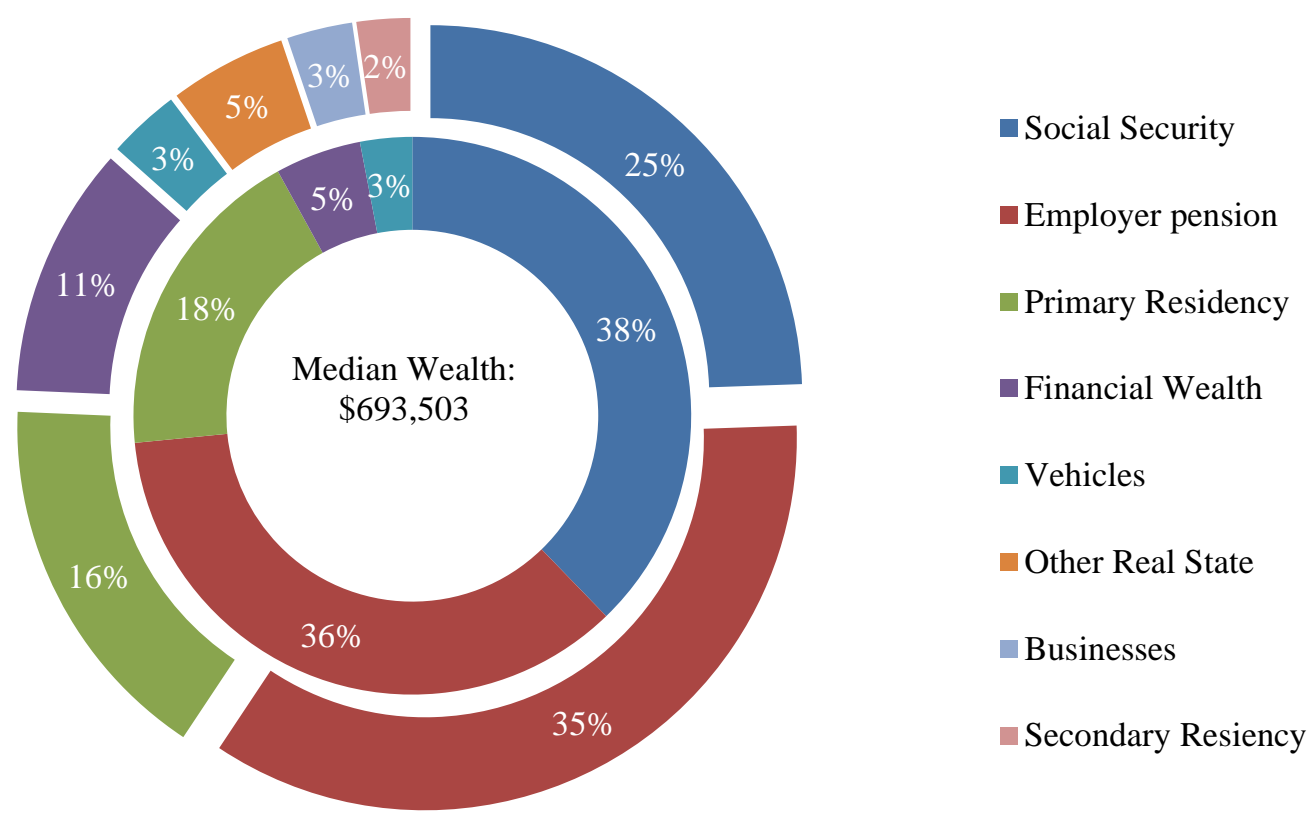

Average Wealth: $\$ 855,439$

Source: RAND HRS Data File, Kapinos et al. (2016), Kapinos and Fang (2016) and Gustman, Steinmeier and Tabatabai (2014).

Note: The sample is limited to male veterans who served less than five years, enlisted in years up to 1972, and left active service at age 25 or younger, and who are between 60 and 62 years old in the HRS. The calculations exclude spouses' prospective Social Security wealth and wealth from spouses' employer-sponsored pension plans.

We estimate the linear regression models depicted in equation

(3), where $Y_{i t}$ is the

hyperbolic sine transformation of the wealth variable $\left(W_{i t}\right)$ of interest, i.e., $Y_{i t}=\log \left(W_{i t}+\right.$

$\left.\sqrt{W_{i t}^{2}+1}\right)$. The variable Time $_{i t}$ measures the number of years since the veteran left the military.

The vector $X_{i}$ includes additional controls (race, age at exit from active service, whether the respondent has a disability related to active service, and the Inverse Mills Ratio to control for selectivity into veteran status). As before, we also control for year fixed effects $\left(\gamma_{t}\right)$ in the regression and standard errors are clustered at the individual level. Since we want to measure preretirement wealth, we only include veterans younger than 62 in our estimation sample. 
The model in equation (3) is similar to the one in equation (2), but given that we have fewer observations in the case of wealth measures than in the case of earnings, we estimate only linear effects of the time passed since re-entering the civilian life, rather than several discrete time-varying effects as in equation (2). ${ }^{16}$ However, wealth variables do not exhibit an inverted U-shape as in the case of earnings. Figure 7 shows that wealth variables have a linear trend, at least for the range of years after active service that are observed in the HRS. Thus, specifying linear effects of time (and its interaction with the unemployment rate at exit from the military) instead of a more flexible form should not be a cause for concern.

$y_{i t}=\alpha+\beta_{1} U R_{i}+\beta_{2}\left(\right.$ Time $\left._{i t}-35\right)+\beta_{3}\left[\left(\right.\right.$ Time $\left.\left._{i t}-35\right) \times U R_{i}\right]+\beta_{4} X_{i}+\gamma_{t}+\epsilon_{i t}$

To simplify the interpretation of the coefficients in equation (3), we centered the years passed since leaving active service at 35 , which is the mean in the sample. ${ }^{17}$ In this way the we can interpret the coefficient $\beta_{1}$ as the average effect (measured in percentage change) of one additional percentage point in the unemployment rate at the time of leaving the military on the veterans’ wealth 35 years later, which corresponds in our sample to an average age of 57. Coefficient $\beta_{3}$ measures how that effect changes with one additional year. As before, we also estimate 2SLS models, in which we instrument $U R_{i}$ and $\left(\right.$ Time $\left._{i t}-35\right) \times U R_{i}$ with $\overline{U R_{\iota}}$ and $\left(\right.$ Time $\left._{i t}-35\right) \times \overline{U R_{l}}$, (average unemployment rate in years two to three after enlistment). The estimation results of coefficients $\beta_{1}$ and $\beta_{3}$ are shown in Table 6 and Table 7 . The 2SLS model

\footnotetext{
16 Since the HRS surveys individuals 50 and older, we have fewer observations regarding wealth measures per individual than in the case of earnings, which uses historical data from Social Security administrative records.

17 Recall that we are only including veterans younger than 62, so the average time passed since leaving the military is shorter than for the full sample shown in Table A1.
} 
delivers larger estimates suggesting a potential combination of veterans with better earnings capacity being able to time their exit from the military and also measurement error issues. ${ }^{18}$

\section{Figure 7: Main walth components and time since leaving active service}

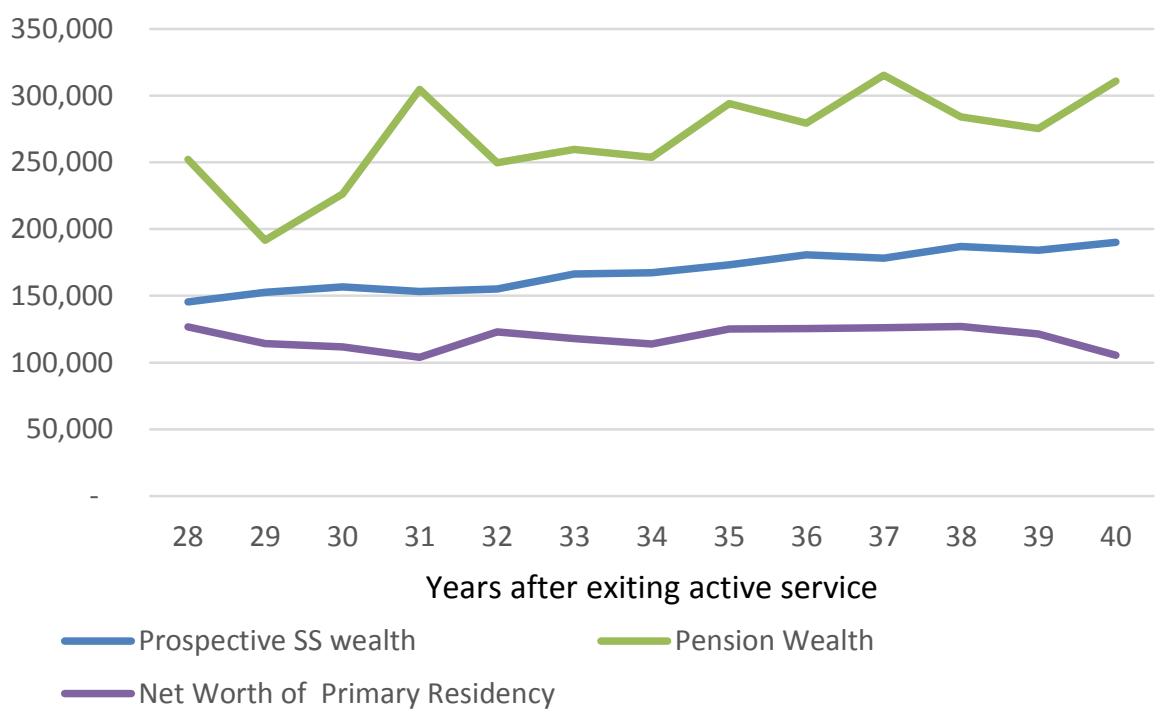

We find that veterans who entered the labor market during times of higher unemployment have lower prospective Social Security wealth (Table 6). This finding correlates with our previous results on negative effects in earnings. A 1-percentage-point increase in the unemployment rate reduces the prospective Social Security wealth 35 five years after leaving active service by 7.4 percent in the 2SLS model.

We also find a positive estimate for $\beta_{3}$, indicating that the negative effect diminishes with time. Using the results from the 2SLS model, we plot in Figure 8 the evolution of the marginal effects of a 1-point increase in the unemployment rate at the time of leaving the military on the prospective Social Security wealth. We observe how the estimated negative effects get smaller

\footnotetext{
18 The lowest Shea's partial $R^{2}$ is still relatively large suggesting that we do not have a problem of weak instruments.
} 
with time and become not statistically significant 40 years after leaving the military. Table 6 also shows, interestingly, that we do not obtain any statistically significant effect of the unemployment rate on wealth from employer-sponsored pension plans.

\section{Table 6: Unemployment rate at exit from active service, prospective Social Security wealth and employer pension wealth}

\begin{tabular}{|c|c|c|c|c|}
\hline \multirow[b]{2}{*}{ VARIABLES } & \multicolumn{2}{|c|}{$\begin{array}{c}\text { Social Security Prospective } \\
\text { Wealth }\end{array}$} & \multicolumn{2}{|c|}{$\begin{array}{c}\text { Employer Pension } \\
\text { Wealth }\end{array}$} \\
\hline & OLS & 2SLS & OLS & 2SLS \\
\hline $\begin{array}{l}\text { Unemp. rate } \\
\text { (in percentage points) }\end{array}$ & $\begin{array}{l}-0.0309 * \\
(0.0168)\end{array}$ & $\begin{array}{c}-0.0736 * * * \\
(0.0269)\end{array}$ & $\begin{array}{c}0.0472 \\
(0.0417)\end{array}$ & $\begin{array}{c}0.0856 \\
(0.0763)\end{array}$ \\
\hline Years since left active service -35 & $\begin{array}{c}0.0378^{* *} \\
(0.0190)\end{array}$ & $\begin{array}{c}0.0133 \\
(0.0300)\end{array}$ & $\begin{array}{c}0.0517 \\
(0.0443)\end{array}$ & $\begin{array}{l}-0.0302 \\
(0.0666)\end{array}$ \\
\hline $\begin{array}{l}\text { (Unemp. Rate) } X \\
\text { (Years since left active service - } \\
\text { 35) }\end{array}$ & $\begin{array}{l}0.00505 \\
(0.00400)\end{array}$ & $\begin{array}{l}0.00988 \\
(0.00660)\end{array}$ & $\begin{array}{l}-0.00550 \\
(0.00633)\end{array}$ & $\begin{array}{r}0.0113 \\
(0.0137)\end{array}$ \\
\hline Inverse Mills Ratio & $\begin{array}{l}0.763 * \\
(0.395)\end{array}$ & $\begin{array}{l}1.074 * * \\
(0.437)\end{array}$ & $\begin{array}{l}-1.566 \\
(2.009)\end{array}$ & $\begin{array}{l}-1.690 \\
(2.045)\end{array}$ \\
\hline Observations & 3,718 & 3,718 & 5,610 & 5,610 \\
\hline \# instrumented regressors & & 2 & & 2 \\
\hline Lowest Shea's Adj. Partial $R^{2}$. & & 0.3293 & & 0.3031 \\
\hline $\begin{array}{l}\text { Notes: Includes only one observation pe } \\
\text { limited to male veterans who served less } \\
25 \text { or younger. Other controls include: } r \\
\text { disability related to active service and ye } \\
\text { individual level. } * * * \text { denotes p-value }<0\end{array}$ & $\begin{array}{l}\text { spondent in the } \\
\text { an } 5 \text { years, enlis } \\
\text { age at exit fror } \\
\text { fixed effects. St } \\
\text {,** denotes p- }\end{array}$ & $\begin{array}{l}\text { S (after poolin } \\
\text { in years up to } \\
\text { tive service, w } \\
\text { ard errors (in p } \\
e<0.05, * \text { deno }\end{array}$ & $\begin{array}{l}\text { 1992-2012). } \\
\text { d left active } s \\
\text { e respondent } \\
\text { es) are cluste } \\
\text { ue }<0.1\end{array}$ & $\begin{array}{l}\text { sample is } \\
\text { ce at age } \\
\text { a } \\
\text { at the }\end{array}$ \\
\hline
\end{tabular}

Table 7 suggests that a higher unemployment rate at the time of separation from the military could lead to a significantly smaller household total net worth (excluding prospective Social Security wealth, employer-sponsored retirement wealth, and other retirement accounts), although the effects are not statistically significant. Using the 2SLS model, our point estimates 
indicate that a 1-percentage-point increase in the unemployment rate at the time of exit is associated with a 22.3 percent reduction in the household total net worth 35 years after exit from active service, and this effect is reduced slowly with time. Note, however, that these effects are estimated imprecisely and are not statistically significant. The 2SLS model produces similar effects of the unemployment rate on the two major components of the total net worth: the net financial wealth (i.e., savings and investments) and the net value of the primary residency.

\section{Figure 8: Unemployment rate at exit from active service and prospective Social Security wealth (marginal effects)}

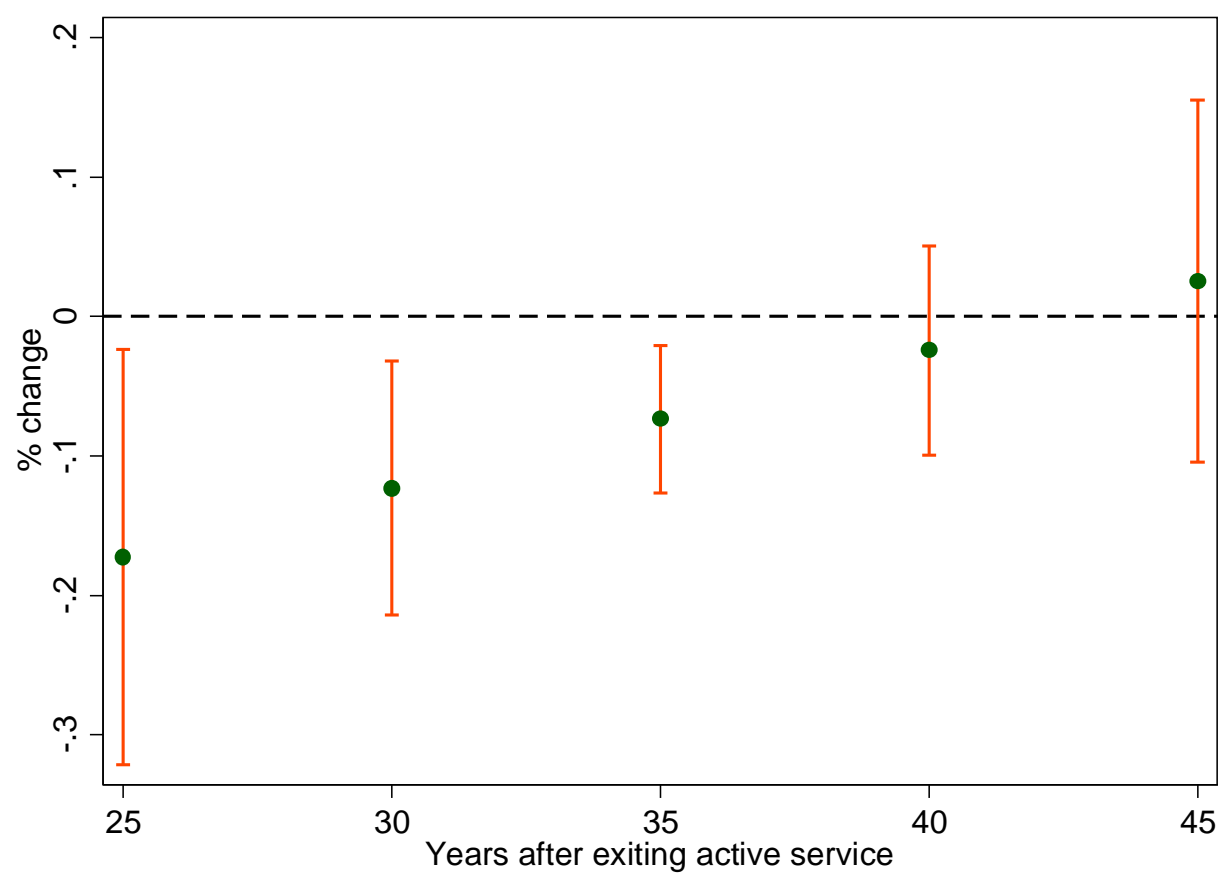

Taken together, our findings indicate that higher unemployment rates at the time of exit from the military can negatively affect veterans’ wealth in old age and their financial preparedness for retirement. In particular, we find negative effects on Social Security wealth even 35 years after leaving the military. This effect is important, because Social Security is one 
of the main sources of wealth in retirement (Figure 6). However, we also find that veterans might eventually catch up with their peers who entered the civilian labor market in better economic conditions. The strong negative effects that we estimate on other measures of wealth are uniformly negative, but they are not statistically significant. In the next subsection, we investigate whether this suggestive evidence of the negative effects on preretirement wealth correlates with effects regarding working in old age and retirement.

Table 7: Unemployment rate at exit from active service and net total worth (excludes prospective Social Security wealth, employer-sponsored retirement wealth and other retirement accounts)

\begin{tabular}{|c|c|c|c|c|c|c|}
\hline \multirow[b]{3}{*}{ VARIABLES } & \multirow{2}{*}{\multicolumn{2}{|c|}{ Net Total Worth }} & \multicolumn{4}{|c|}{ Main components of Total Net Worth: } \\
\hline & & & \multicolumn{2}{|c|}{$\begin{array}{l}\text { Net Financial } \\
\text { Wealth }\end{array}$} & \multicolumn{2}{|c|}{$\begin{array}{c}\text { Primary } \\
\text { Residency Net } \\
\text { Worth }\end{array}$} \\
\hline & OLS & 2SLS & OLS & 2SLS & OLS & 2SLS \\
\hline $\begin{array}{l}\text { Unemp. rate } \\
\text { (in percentage points) }\end{array}$ & $\begin{array}{l}-0.102 \\
(0.102)\end{array}$ & $\begin{array}{l}-0.223 \\
(0.136)\end{array}$ & $\begin{array}{l}-0.137 \\
(0.140)\end{array}$ & $\begin{array}{l}-0.223 \\
(0.222)\end{array}$ & $\begin{array}{l}0.00218 \\
(0.0994)\end{array}$ & $\begin{array}{l}-0.219 \\
(0.157)\end{array}$ \\
\hline Years since left active service -35 & $\begin{array}{l}-0.122 \\
(0.166)\end{array}$ & $\begin{array}{c}0.00382 \\
(0.245)\end{array}$ & $\begin{array}{c}-0.00776 \\
(0.187)\end{array}$ & $\begin{array}{c}0.317 \\
(0.297)\end{array}$ & $\begin{array}{l}-0.0300 \\
(0.137)\end{array}$ & $\begin{array}{l}0.0538 \\
(0.214)\end{array}$ \\
\hline $\begin{array}{l}\text { (Unemp. Rate) } X \\
\text { (Years since left active service - } \\
\text { 35) }\end{array}$ & $\begin{array}{r}0.0306 \\
(0.0376)\end{array}$ & $\begin{array}{l}0.00516 \\
(0.0538)\end{array}$ & $\begin{array}{c}0.0261 \\
(0.0373)\end{array}$ & $\begin{array}{l}-0.0393 \\
(0.0613)\end{array}$ & $\begin{array}{l}0.00447 \\
(0.0267)\end{array}$ & $\begin{array}{l}-0.0117 \\
(0.0436)\end{array}$ \\
\hline Inverse Mills Ratio & $\begin{array}{l}-4.602 \\
(3.418)\end{array}$ & $\begin{array}{l}-3.875 \\
(3.495)\end{array}$ & $\begin{array}{l}-4.072 \\
(5.040)\end{array}$ & $\begin{array}{l}-3.757 \\
(5.178)\end{array}$ & $\begin{array}{l}-8.058 * \\
(4.600)\end{array}$ & $\begin{array}{l}-6.501 \\
(4.679)\end{array}$ \\
\hline Observations & 7,454 & 7,454 & 8,401 & 8,401 & 8,401 & 8,401 \\
\hline \# instrumented regressors & & 2 & & 2 & & 2 \\
\hline Lowest Shea's Adj. Partial $R^{2}$. & & 0.3533 & & 0.3482 & & 0.3482 \\
\hline $\begin{array}{l}\text { Notes: Includes only one observation pe } \\
\text { male veterans who served less than five } \\
\text { Other controls include: race, age at exit } \\
\text { and year fixed effects. Standard errors } \\
\text { denotes p-value }<0.05 \text {, * denotes p-value }\end{array}$ & $\begin{array}{l}\text { spondent i } \\
\text { ars, enlisted } \\
\text { m active se } \\
\text { arentheses } \\
.1\end{array}$ & $\begin{array}{l}\text { the HRS ( } \\
\text { in years up } \\
\text { vice, wheth } \\
\text { are cluster }\end{array}$ & $\begin{array}{l}\text { pooling way } \\
72 \text {, and left } \\
\text { e responden } \\
\text { the individu }\end{array}$ & $\begin{array}{l}\text { 1992-2012 } \\
\text { ctive servic } \\
\text { tas a disabil } \\
\text { level. } * * *\end{array}$ & $\begin{array}{l}\text { le sample is } \\
\text { ge } 25 \text { or yo } \\
\text { elated to act } \\
\text { tes p-value }\end{array}$ & $\begin{array}{l}\text { limited to } \\
\text { inger. } \\
\text { ve service, } \\
0.01 \text {, ** }\end{array}$ \\
\hline
\end{tabular}




\section{Effect on working in old age and retirement}

We find that veterans who reentered the civilian life in periods of high unemployment seem eventually to catch up in terms of earnings and wealth with their peers. The evidence presented in Section 6, that higher unemployment rates at the time of leaving the military are associated with higher probability of having positive earnings 40 years later, suggests that extending their working lives may be one way in which veterans compensate for entering the labor market under less-than-ideal circumstances. In this section, we revisit this finding using information from veterans' reported labor force status instead of records from Social Security and controlling from age instead of time passed since leaving the military. We also investigate how the unemployment rate when exiting active service affects veterans’ decisions to claim Social Security benefits.

We estimate the model in equation (4), which is similar to that in equation (2), but in this case we use a set of indicator variables $A g e_{a, i}$ that take the value of 1 if the veteran is in age category $a$, and take the value of zero otherwise. We use the following age categories in our analysis: 50 to 61 years, 62 to less than normal retirement age (NRA); NRA to 69; 70 to $74 ; 75$ to 79; and 80 and older. ${ }^{19}$ All other variables on the right-hand side are defined as before, and standard errors are clustered at the individual level. In the 2SLS models, we instrument $A g e_{a, i t} \times$ $U R_{i}$ with $A g e_{a, i t} \times \overline{U R_{\iota}}$, where $\overline{U R_{\iota}}$ is the average unemployment rate two to three years after enlistment.

$$
Y_{i t}=\sum_{k=1}^{6} \beta_{T, k} A g e_{a, i t}+\sum_{k=1}^{6} \beta_{U R, k}\left(A g e_{a, i t} \times U R_{i}\right)+\beta_{X} X_{i}+\gamma_{t}+\epsilon_{i t}
$$

\footnotetext{
19 We measure age in months at the beginning of the HRS interview and define the NRA in months based on the year of birth.
} 
In our first analysis, the dependent variable $Y_{i t}$ is an indicator variable that equals 1 if the veteran reports working full or part-time or looking for a job, and equals 0 otherwise. The estimation results for the coefficients $\beta_{U R, k}$ are shown in Table 8 . We find that veterans who left military service in periods of high unemployment are more likely to work or search for work in old age. The largest effect is in the 62 to NRA range: a 1-percentage-point increase in the unemployment rate at the time of leaving active service increases the probability of working or looking for work in this age range by 3.7 percentage points in the OLS model, and by 4.7 percentage points in the 2SLS model. The estimated effects remain positive but are smaller at higher ages.

In our second analysis, we estimate the same linear model in equation (4), but the dependent variable $Y_{i t}$ is an indicator variable that equals 1 if the veteran has already claimed Social Security, and equals zero otherwise. We keep in the analysis sample all observations until the veteran first receives social security, and exclude all later observations. Thus, we are estimating a discrete hazard rate of claiming Social Security conditional on not having claimed before. The estimation results for the coefficients $\beta_{U R, k}$ are also shown in Table 8. The OLS models suggest that veterans who reentered the civilian labor market in periods of high unemployment are less likely to claim Social Security early, between the age of 62 and the NRA. In contrast, they are more likely to claim after the NRA in comparison to their peers, conditional on not having claimed earlier. As it would be expected, the effect on the hazard rate decreases with age (after reaching NRA) and eventually becomes small and non-significant. The 2SLS estimates follow the same pattern: negative effects on the hazard rate prior to reaching NRA, positive effects after reaching NRA, and eventually small effects. However, the effects are not statistically significant in the 2SLS model except for the 70 to 74 age category. 
Table 8: Unemployment rate at exit from active service, work in old age and claiming of Social Security benefits.

\begin{tabular}{|c|c|c|c|c|}
\hline \multirow[b]{2}{*}{ VARIABLES } & \multicolumn{2}{|c|}{$\begin{array}{l}\text { Working or looking for } \\
\text { work }\end{array}$} & \multicolumn{2}{|c|}{$\begin{array}{c}\text { Claim Social Security } \\
\text { Benefits (Discrete Hazard } \\
\text { Rate) }\end{array}$} \\
\hline & OLS & 2SLS & OLS & 2SLS \\
\hline $50-61$ & $\begin{array}{c}0.012 * \\
(0.007)\end{array}$ & $\begin{array}{l}0.019 * \\
(0.010)\end{array}$ & $\begin{array}{c}-0.006^{*} \\
(0.003)\end{array}$ & $\begin{array}{l}-0.006 \\
(0.004)\end{array}$ \\
\hline 62 to less than NRA & $\begin{array}{c}0.037 * * * \\
(0.009)\end{array}$ & $\begin{array}{c}0.047^{* * *} \\
(0.015)\end{array}$ & $\begin{array}{c}-0.022^{* * * *} \\
(0.006)\end{array}$ & $\begin{array}{l}-0.009 \\
(0.015)\end{array}$ \\
\hline NRA to 69 & $\begin{array}{c}0.023 * * * \\
(0.008)\end{array}$ & $\begin{array}{l}0.023 * \\
(0.014)\end{array}$ & $\begin{array}{c}0.041^{* * *} \\
(0.007)\end{array}$ & $\begin{array}{c}0.033 \\
(0.021)\end{array}$ \\
\hline 70-74 & $\begin{array}{c}0.018 * * * \\
(0.006)\end{array}$ & $\begin{array}{c}0.031 * * * \\
(0.011)\end{array}$ & $\begin{array}{c}0.014 * * * \\
(0.005)\end{array}$ & $\begin{array}{c}0.061^{* * *} \\
(0.020)\end{array}$ \\
\hline $75-79$ & $\begin{array}{c}0.014 * * \\
(0.006)\end{array}$ & $\begin{array}{c}0.021^{*} \\
(0.012)\end{array}$ & $\begin{array}{c}0.001 \\
(0.006)\end{array}$ & $\begin{array}{c}0.011 \\
(0.009)\end{array}$ \\
\hline 80 and older & $\begin{array}{c}0.016^{* *} \\
(0.007)\end{array}$ & $\begin{array}{c}0.018 \\
(0.012)\end{array}$ & $\begin{array}{l}-0.002 \\
(0.006)\end{array}$ & $\begin{array}{l}-0.006 \\
(0.004)\end{array}$ \\
\hline Inverse Mills Ratio & $\begin{array}{c}0.042 \\
(0.028)\end{array}$ & $\begin{array}{c}0.040 \\
(0.028)\end{array}$ & $\begin{array}{c}0.088 * * * \\
(0.017)\end{array}$ & $\begin{array}{c}0.084 * * * \\
(0.023)\end{array}$ \\
\hline Observations & 29,262 & 29,262 & 15,886 & 15,886 \\
\hline $\begin{array}{l}\# \text { instrumented regressors } \\
\text { Lowest Shea's Adj. Partial } \\
R^{2} \text {. }\end{array}$ & & 0.299 & & 0.278 \\
\hline $\begin{array}{l}\text { Notes: Includes only one obse } \\
\text { 1992-2012). The sample is lir } \\
\text { enlisted in years up to 1972, } \\
\text { include: indicator variables fo } \\
\text { respondent has a disability re } \\
\text { (in parentheses) are clustered } \\
\text { p-value }<0.05, * \text { denotes p-val }\end{array}$ & $\begin{array}{l}\text { tion per rest } \\
\text { d to male ve } \\
\text { left active se } \\
\text { ge range, rac } \\
\text { d to active st } \\
\text { he individua } \\
0.1\end{array}$ & $\begin{array}{l}\text { ndent in the } \mathrm{F} \\
\text { rans who ser } \\
\text { ice at age } 25 \\
\text { age at exit fr } \\
\text { ice, and year } \\
\text { evel. *** den }\end{array}$ & $\begin{array}{l}\text { SS (after poolin } \\
\text { d less than five } \\
r \text { younger. Oth } \\
\text { n active servic } \\
\text { ixed effects. St } \\
\text { tes p-value }<0 \text {. }\end{array}$ & $\begin{array}{l}\text { aves } \\
\text { rs, } \\
\text { ntrols } \\
\text { iether the } \\
\text { rd errors } \\
\text { * denotes }\end{array}$ \\
\hline
\end{tabular}

Taken together, the results from Table 8 indicate that veterans who left military service in periods of high unemployment are less likely to retire early and more likely to work past their NRA than veterans who exited the military in better economic times. This suggests that although differences in earnings disappear with time, the accumulated negative effects on wealth and financial preparedness for retirement may be large enough that veterans compensate for it by extending their working life. 


\section{Conclusion}

In this study, we investigate the short- and long-term effects on leaving military service in periods of high unemployment. Our sample includes male veterans from the draft era who served for ess than five years and who left active service at 25 or younger. We find that entering the civilian labor market during a period of relatively high unemployment has negative and longterm effects. We find statistically significant, negative, and substantive effects on earnings conditional on receipt for more than a decade. We also find evidence of negative effects on prospective Social Security wealth, although these effects appear to disappear in time, and larger, but not statistically significant, effects on other sources of wealth (savings, investments, and housing). We also find evidence that veterans may try to compensate for these negative effects by delaying retirement and working longer. It is worth noting that these findings hold regardless of the fact that veterans who enter the labor market in weak conditions obtain more postsecondary education than other veterans. Finally, we find that veterans who enter the civilian labor market in periods of high unemployment have higher levels of family instability (i.e., they are more likely to get separated or divorced), which may be another indication of underlying negative effects on the household economic well-being.

Our results add to the evidence that the negative impacts of entering the labor market during an economic downturn are both substantive and very long-lasting. While providing opportunities for additional post-secondary education or training (as the military does) are likely to be helpful to young workers who, by timing of birth, enter the labor market during economic downturns, our results suggest that such programs may not make up for the total impact. Indeed, our results suggest that high unemployment at the time of entering the labor market is likely to 
affect even the decision of when to retire: This suggests the effects occur over a longer time period than what has been addressed in other studies.

Our findings suggest that many of today's younger workers, who entered the labor market during the Great Recession, may respond by extending their working life in order to compensate for the negative starting conditions. Thus, our findings should be of interest to Social Security and to policy analysts forecasting retirement patterns of young workers. Our finding should also be of interest to policymakers working to help smooth current, active-military personnel's transition into the civilian labor force. 


\section{References}

Angrist, Joshua D. 1990. "Lifetime Earnings and the Vietnam Era Draft Lottery: Evidence from Social Security Administrative Records." The American Economic Review, 313-36.

Angrist, Joshua D and Stacey H Chen. 2011. "Schooling and the Vietnam-Era Gi Bill: Evidence from the Draft Lottery." American Economic Journal: Applied Economics, 3(2), 96-118.

Angrist, Joshua D and Jörn-Steffen Pischke. 2008. Mostly Harmless Econometrics: An Empiricist's Companion. Princeton university press.

Angrist, Joshua and Alan B Krueger. 1994. "Why Do World War Ii Veterans Earn More Than Nonveterans?" Journal of labor economics, 12(1), 74-97.

Arkes, Jeremy. 2003. "Does Schooling Improve Adult Health?".

Autor, David; David Dorn and Gordon Hanson. 2017. "When Work Disappears: Manufacturing Decline and the Falling Marriage-Market Value of Men," National Bureau of Economic Research, Inc,

Barry, Catherine. 2013. "New Americans in Our Nation’s Military: A Proud Tradition and Hopeful Future." Center for American Progress.

Beaudry, Paul and John DiNardo. 1991. "The Effect of Implicit Contracts on the Movement of Wages over the Business Cycle: Evidence from Micro Data." Journal of Political Economy, 665-88.

Bound, John and Sarah Turner. 2002. "Going to War and Going to College: Did World War Ii and the Gi Bill Increase Educational Attainment for Returning Veterans?" Journal of labor economics, 20(4), 784-815. 
Brunner, Beatrice and Andreas Kuhn. 2009. "To Shape the Future: How Labor Market Entry Conditions Affect Individuals' Long-Run Wage Profiles." Institute for Empirical Research in Economics, University of Zurich Working Paper, (457).

Card, David and Thomas Lemieux. 2001. "Going to College to Avoid the Draft: The Unintended Legacy of the Vietnam War." The American Economic Review, 91(2), 97-102.

De-Walque, Damien. 2007. "Does Education Affect Smoking Behaviors? Evidence Using the Vietnam Draft as an Instrument for College Education." Journal of Health Economics, 26, 877-95.

Genda, Yuji; Ayako Kondo and Souichi Ohta. 2010. "Long-Term Effects of a Recession at Labor Market Entry in Japan and the United States." Journal of Human Resources, 45(1), 157-96.

Gustman, Alan L.; Thomas L. Steinmeier and Nahid Tabatabai. 2014. "Updated Pension Wealth Data Files in the Hrs Panel: 1992 to 2010 - Part Iii," Ann Arbor, Michigan: Institute for Social Research, University of Michigan,

Heckman, James J. 1979. "Sample Selection Bias as a Specification Error." Econometrica: Journal of the Econometric Society, 153-61.

Hershbein, Brad J. 2012. "Graduating High School in a Recession: Work, Education, and Home Production." The BE journal of economic analysis \& policy, 12(1).

HRS. "Health and Retirement Study, Core Files 1992-2012 Public Use Dataset.," Produced and distributed by the University of Michigan with funding from the National Institute on Aging (grant number NIA U01AG009740). Ann Arbor, MI, (2016),

$\ldots$ _ "Health and Retirement Study, Respondent Cross-Year Summary Earnings. Restricted Use Dataset. Version 4.0.," Produced and distributed by the University of Michigan with 
funding from the National Institute on Aging (grant number NIA U01AG009740). Ann Arbor, MI, (2016),

Kahn, Lisa B. 2010. "The Long-Term Labor Market Consequences of Graduating from College in a Bad Economy." Labour Economics, 17(2), 303-16.

Kapinos, Kandice; Charlie Brown; Michael Nolte; Helena Stolyarova and David Weir. 2016. "Health and Retirement Study. Prospective Social Security Wealth Measures of PreRetirees. Public Release. Version 5.0. Data Description and Usage," Ann Arbor, Michigan: Survey Research Center, Institute for Social Research, University of Michigan,

Kapinos, Kandice and Chichun Fang. 2016. "Health and Retirement Study. Prospective Social Security Wealth Measures of Pre-Retirees. Wave 10. Data Description and Usage," Ann Arbor, Michigan: Institute for Social Research, University of Michigan,

Loughran, David S; Paco Martorell; Trey Miller and Jacob Alex Klerman. 2011. "The Effect of Military Enlistment on Earnings and Education. Technical Report." RAND Corporation. Oreopoulos, Philip; Till von Wachter and Andrew Heisz. 2012. "The Short-and Long-Term Career Effects of Graduating in a Recession." American Economic Journal: Applied Economics, 4(1), 1-29.

Oyer, Paul. 2006. "Initial Labor Market Conditions and Long-Term Outcomes for Economists." The Journal of Economic Perspectives, 20(3), 143-60. 2008. "The Making of an Investment Banker: Stock Market Shocks, Career Choice, and Lifetime Income." The Journal of Finance, 63(6), 2601-28. 
RAND. "Rand Hrs Data, Version O. Produced by the Rand Center for the Study of Aging, with Funding from the National Institute on Aging and the Social Security Administration. Santa Monica, Ca (October 2015)."

Rostker, Bernard. 2006. "I Want You! The Evolution of the All-Volunteer Force.," Santa Monica, CA: RAND Corporation,

Schafer, Amy. 2017. "Generations of War: The Rise of the Warrior Caste \& the All-Volunteer Force," Military, Veterans \& Society Report Center for a New American Security,

Shea, John. 1997. "Instrument Relevance in Multivariate Linear Models: A Simple Measure." The Review of Economics and Statistics, 79(2), 348-52.

Sohoni, Deenesh and Amin Vafa. 2010. "The Fight to Be American: Military Naturalization and Asian Citizenship." Asian Am. LJ, 17, 119.

StataCorp. 2013. "Stata Statistical Software: Release 13," College Station, TX: StataCorp LP, 


\section{Appendix}

Table A1: Sample statistics

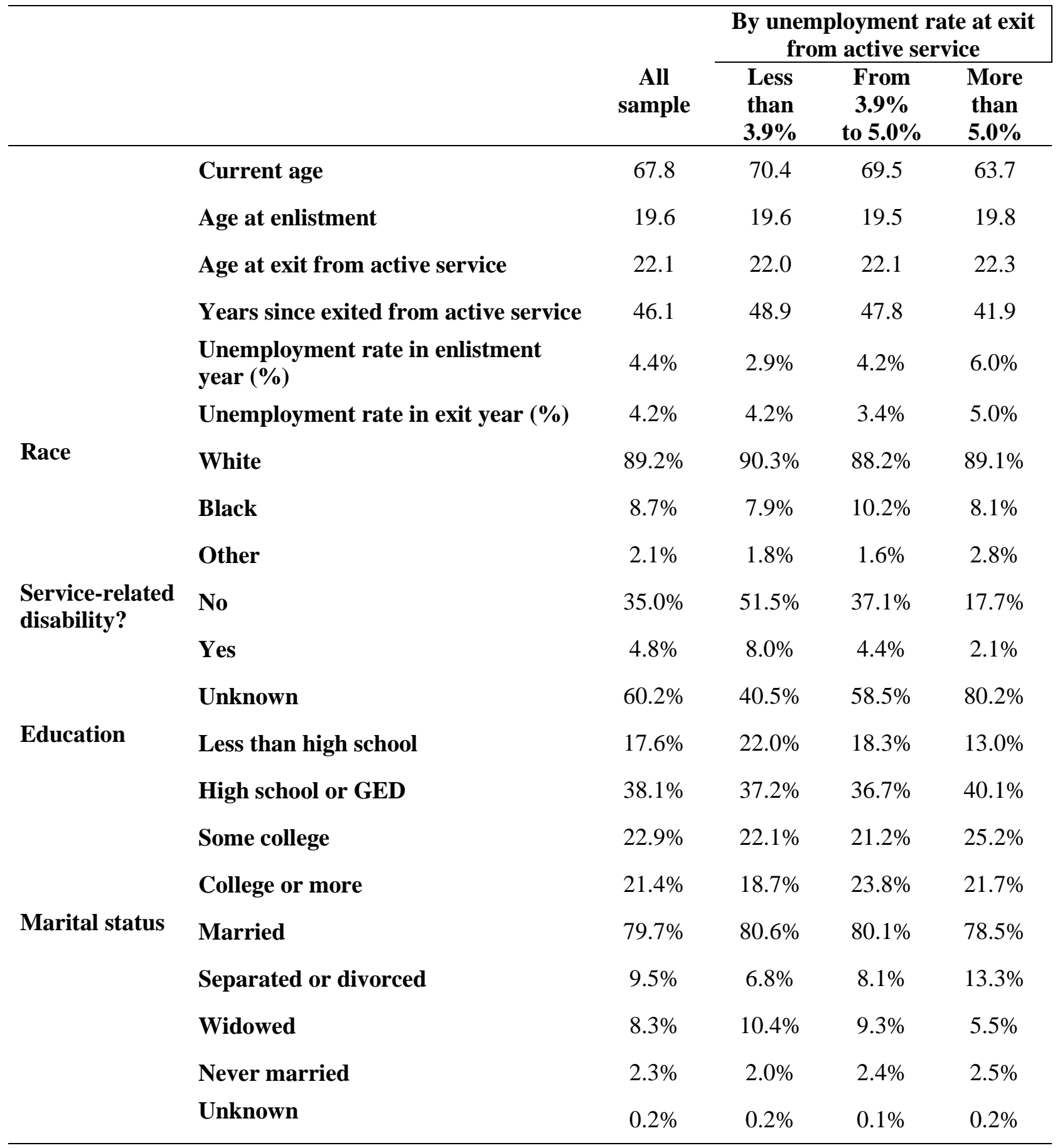

Note: Means from all person-year observations in the sample, unless otherwise noted. 
Table A1: Sample statistics (continued)

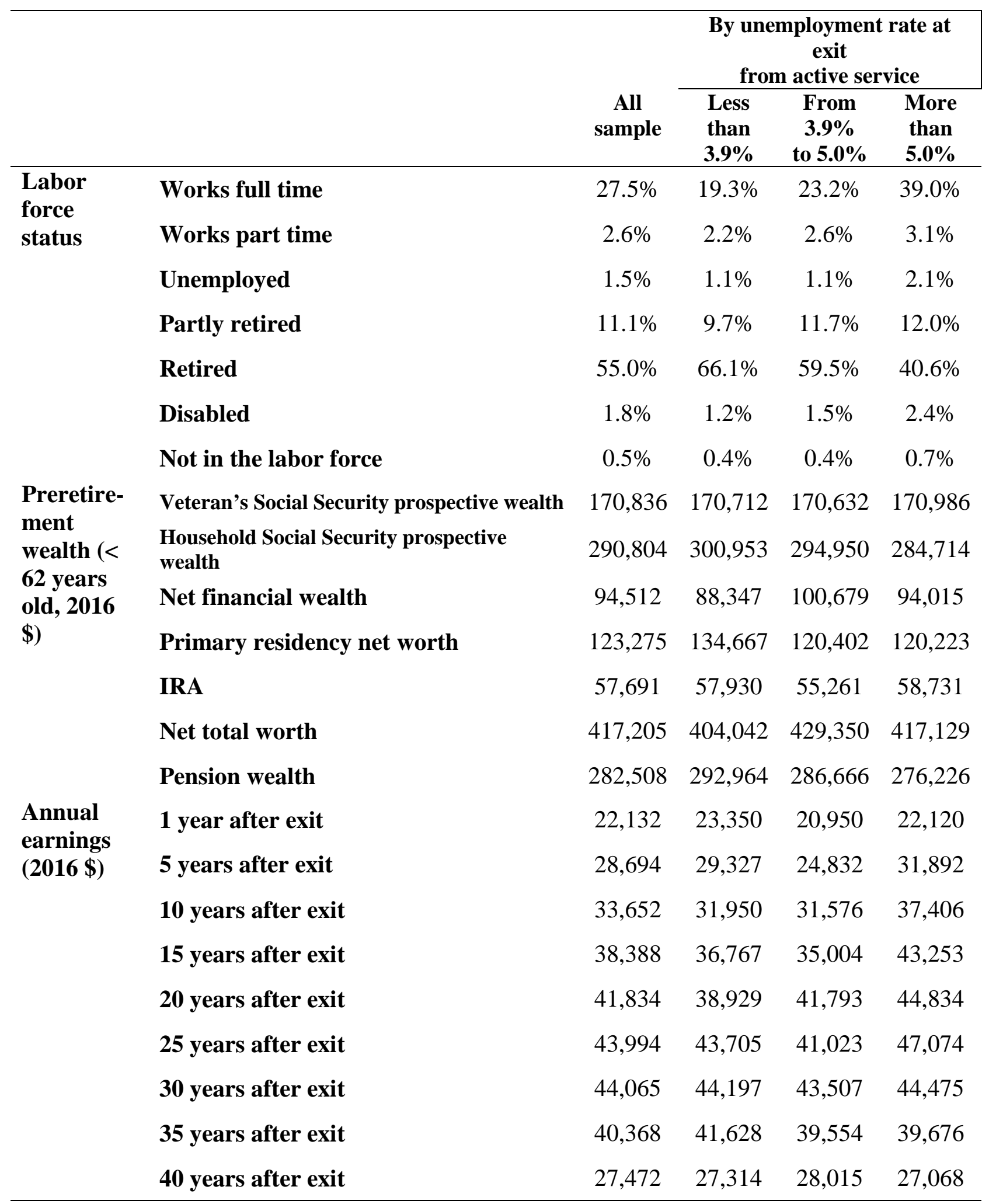

Note: Means from all person-year observations in the sample, unless otherwise noted. 


\section{Table A2: First stage regression for instrumenting unemployment rate at time of exit from active service}

Outcome:

Unemployment rate in year of exit from active service

Average unemployment rate in years 2-3 after enlistment

(in percentage points)

Race (Omitted category: White)

Black

Other

Age at exit from active service

Service related disability

Yes

Unknown

Inverse Mills Ratio
$0.789 * * *$

(0.014)

$0.105^{* *}$

$0.366 * * *$

(0.106)

$0.042 * * *$

(0.008)

$-0.340 * * *$

(0.077)

0.230

$(0.183)$

Observations

4,444

Notes: Includes only one observation per respondent in the HRS (after pooling waves 1992-

2012). The sample is limited to male veterans who served less than 5 years, enlisted in years up to 1972, and left active service at age 25 or younger. Standard errors in parentheses. ${ }^{* * *} \mathrm{p}<0.01$, ** $\mathrm{p}<0.05, * \mathrm{p}<0.1$ 
Figure A1: The inverse hyperbolic sine function

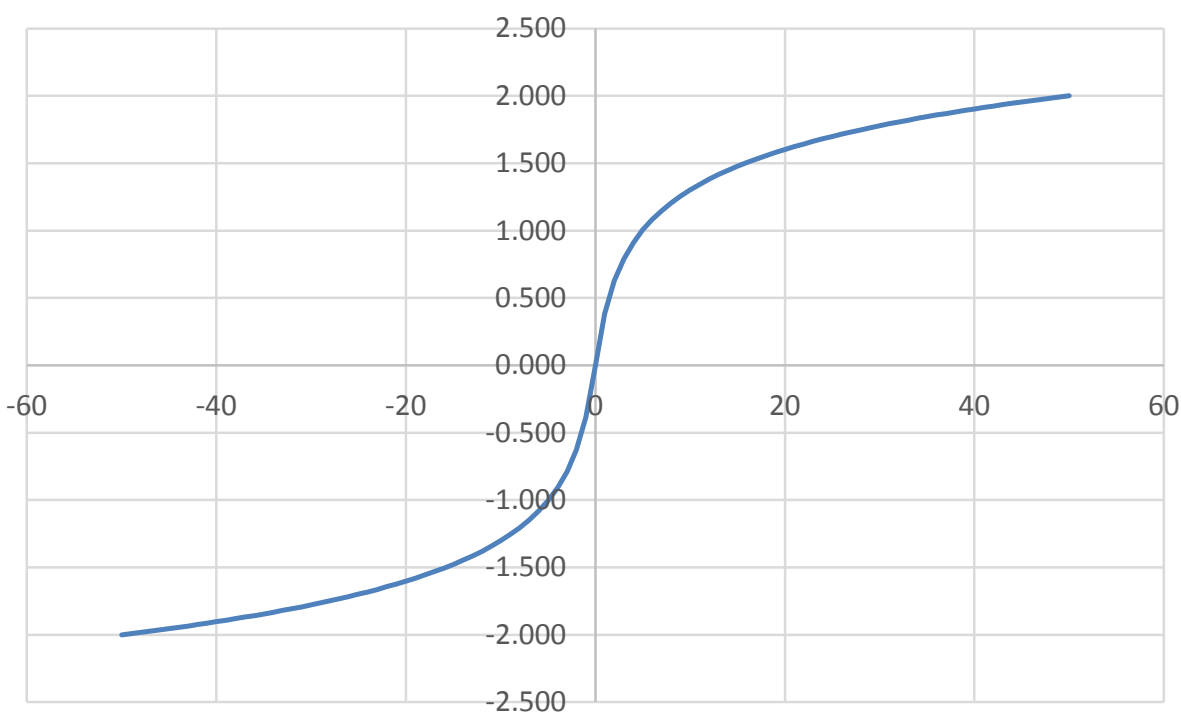

